\title{
ResearchOnline@JCU
}

This is the author-created version of the following work:

Le Queux, Stephane, and Kuah, Adrian (2021) Junzi leadership in Singapore: governance and human capital development. Journal of Management Development, 40 (5) pp. 389-403.

Access to this file is available from: https://researchonline.jcu.edu.au/62616/

(C) Emerald Publishing Limited. In accordance with the publisher's policies, the Author Accepted Manuscript of this article is available Open Access from ResearchOnline@JCU.

Please refer to the original source for the final version of this work: https://doi.org/10.1108/JMD\%2D05\%2D2019\%2D0194 


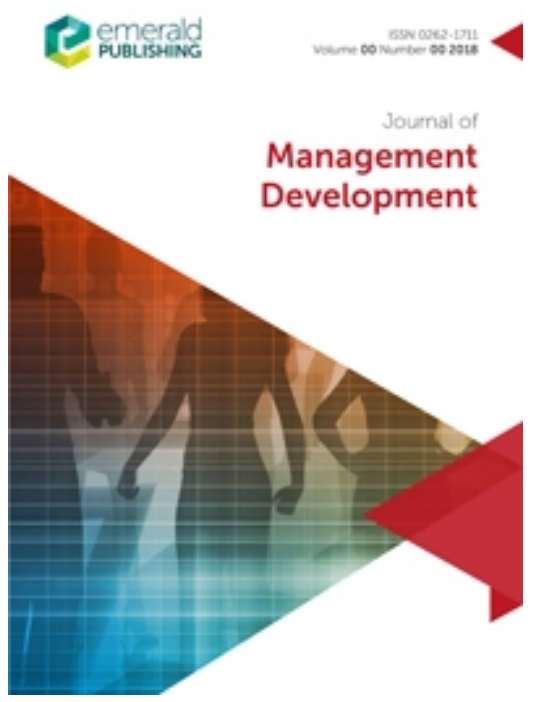

君子 Junzi Leadership in Singapore: Governance and Human Capital Development

\begin{tabular}{|r|l|}
\hline Journal: & Journal of Management Development \\
\hline Manuscript ID & JMD-05-2019-0194.R1 \\
\hline Manuscript Type: & Original Article \\
\hline Keywords: & $\begin{array}{l}\text { Leadership, Governance, Singapore, Tripartism, Confucius, Human } \\
\text { capital development }\end{array}$ \\
\hline
\end{tabular}




\section{君子 Junzi Leadership in Singapore: \\ Governance and Human Capital Development}

\section{Purpose}

This paper provides insights as to how a Confucian inspired Junzi style of leadership translates into initiatives towards human capital development in Singapore. After reviewing tripartite governance in Singapore, we discuss the character of Confucian leadership: how does this value system inform the moral economy of the Singaporean corporatist model and inherently come to impact upon the conception and significance of human capital.

\section{Design/methodology/approach}

The case approach was employed using multiple sources of secondary data, supplemented by interviews with high-profile informants in Singapore. Multiple sources led to data triangulation in presenting a mutually consistent set of evidence. The paper also draws from a longitudinal observation of Singapore's industrial relations and human resource development (HRD) policies over the last 10 years since the Global Financial Crisis.

\section{Findings}

Organized along two thematic areas: governance and human capital development, this paper proposes and finds that governance in Singapore displays an institutionalized form of Junzi leadership that translates into policy-making toward human capital development.

\section{Originality/value}

This paper brings about an Asian perspective of Junzi leadership toward management and governance. The Confucian value system intrinsic to tripartite governance provides an original heuristic lens that help shed a light on the significance of human capital development in Singapore. 


\section{Introduction}

Singapore has a specific form of leadership and governance, a unique brand of 'ultracorporatism' (Kuah et al., 2017), which arguably provides successful policy-making. The virtue of social dialogue at the epicenter of the EU social model has long been heralded yet proved arduous in monitoring its success, thereby leading to the search for a better "governance architecture" (Armstrong, 2012). In contrast, the tripartite governance in Singapore displays dynamic features of agile coordination enabling quick adjustments which bore fruit, as demonstrated by Singapore's sustained economic success.

Tripartite governance becomes the backbone of Singapore's socioeconomic model, but more importantly, it is labour-centric. The development of human capital is indeed core to Singapore's economic development because of the city-country's lack of natural resources. As stated by Coe and Kelly (2000, p. 414), "there can be few other places in the world where the social regulation of the labour market has been so consistently and explicitly a central component of national development strategy as it has been in Singapore." As such, Singapore is a living laboratory that epitomizes the potential of systemic investment in human capital.

This paper looks at the fabric of tripartite governance, in particular how Tripartism has evolved in Singapore to address labour shortage challenges, and finally how tripartite policies are embedded to enhance human capital development (Leggett, 2013). In doing so, the paper discusses how a Confucian ethos inspired Singaporean leaders and gave ground to the Singaporean model of governance. It is argued that this ethos, in lieu of "political ideology" (Barr, 2000), informs the moral economy underpinning the Singaporean corporatist model. As a review paper, it does not make an attempt to draw a linear connection between leadership and human capital in the form of a straight relationship between independent and dependent variables. Instead, the paper focuses how leadership molds into a model of 
governance, of which Tripartism is a key institutional feature instrumental to the development of HRD strategies (Osman-Gani and Tan, 1998, p. 421). This is consistent with Miao et al (2012: 391) who suggest that "the main focus of research into Asian leadership should be on examining how the mix of cultural and wider contextual influences, such as particular socioeconomic and industrial contexts, along with particular industrial work dynamics, impact on follower responses to transformational leadership."

The data used is informed by a 10-year longitudinal review of Singapore industrial relations and HRD policies between 2009 and 2019. External validation was sought through openended interviews with union leaders, directors of employers' associations, directors of closely held government agencies, and a Minister of State for the Ministry of Manpower. Scott's (1990) criteria were used to assess the authenticity, creditability, representativeness, and meaning to information, while Silverman's (2000) technique was used to treat interview data. The paper is organized along two thematic areas, governance and human capital, as follows: we first review tripartist governance in Singapore and how this has evolved over time to address contemporary and future challenges. Arising from this, we illustrate how this model of governance delivered shared prosperity in delivering both economic and wage growth. Next, we discuss the character of Confucian leadership. Further, we exemplify how such a model of governance and leadership translates into initiatives toward human capital development and may provide a lead for best practices regionally, concluding that considering Confucian value system is a valuable heuristic to understand leadership and governance in Asia and does impact on the meaning and significance of human capital in Singapore.

\section{The Fabric of Tripartism}


Tripartism refers to an economic corporatism based on tripartite contracts between business, labour, and the State within the economy. Each party acts as a social partner to create an economic policy through cooperation, consultation, negotiation, and compromise (Wiarda, 1996). Tripartism in Singapore is arguably a key reason supporting Singapore's economic advancement into a highly developed trade-oriented economy (Leggett et al., 2017; Kuah et al, 2017). This tripartite arrangement has been a platform for the Singapore government to launch a wide range of schemes to boost productivity growth, encourage skills upgrading, and even forge consensus on national wage guidelines.

On the one hand, employers' associations and trade union members in Singapore support the government's initiatives to adopt a non-confrontational labour relations practice. All parties partake in labour relations and share a belief to work toward an 'amicable and harmonious' outcome that is not disruptive to work. On the other hand, Singapore's political elite adopted the concept of patriarchalism to bolster Singapore's "tripartite arrangements by absorbing key employer interests in building collaborative relationships vital for the developmental state" (Sheldon et al., 2015, pp. 441).

The major players in the Singapore tripartite movement include the Singapore National Employers Federation (SNEF), National Trade Union Congress (NTUC), and Ministry of Manpower (MOM). The formation of the NTUC by the ruling political party (the People's Action Party, or PAP) in 1964 provided a strategic thrust to propel its industrial relations initiatives that led to the government favoring cooperation with labour unions and forging strong alliances with businesses in Singapore (Haley et al., 1996). The unique PAP-NTUC relationship became the core of a wider tripartite system. It has become common to find senior officials in public service being seconded into the NTUC to boost the quality and standing of the NTUC leadership. Able union leaders, in turn, are also co-opted into the PAP 
leadership, fielded as Members of Parliament (MP) and appointed to key offices, enabling cross-fertilization and knowledge exchanges.

The opportunity to seal the tripartite industrial relations occurred in 1980 when the Ministry of Labour (renamed the Ministry of Manpower-MOM in 1998) effected a merger between the two then largest registered employers' associations (the Singapore Employers' Federation and the National Employers' Council) into the SNEF. The SNEF's ruling Council is made up of 14 representatives from leading companies and multinational corporations in Singapore. The SNEF sets a common agenda on issues such as innovation, productivity, and skills upgrading but still must work within a system where the NTUC-PAP interests have been self-styled as "symbiotic" (Leggett et al., 2017; Loh, 2018, p. 2). The MOM is in charge of orchestrating labour deployment and HRD to meet the needs of companies and multinational corporations in Singapore. Over the years, the MOM has deployed multiple strategies to implement manpower planning, lifelong employability, the augmentation of talent, and the transformation of the work environment (MOM, 2001).

\section{Tripartite Success: Economic and Wage Growth}

To ensure that wage-share grows in tandem with productivity and economic growth in Singapore, a tripartite National Wages Council (NWC) was set up in 1972. Later, in 1979, the PAP adopted a corrective high-wage policy to orchestrate belated economic restructuring. This high-wage policy by the NWC induced a shift in Singapore's economy toward high technology and high value-added production. However, this required a parallel shift in the management and development of the labour market. The regulatory means for skills formation and "character building" were set up by government agencies, the NTUC and the SNEF. Workforce development increasingly became a tripartite endeavor. Leggett, Kuah and Gan (2017) assert that nowhere have Singapore's employers' associations engaged more in 
tripartite relations than in the centralized wage determination of NWC. In making its recommendations on wage adjustments for the year, the tripartite NWC takes into consideration factors such as productivity growth, employment situation, international competitiveness, and economic growth and prospects.

Singapore successfully made a swift and remarkable recovery from the Global Financial Crisis (GFC) of 2007-2008. After a peak at over 15.24\% average GDP growth across four quarters in 2010 (World Bank, 2019), GDP growth rates have remained relatively steady throughout the rest of the decade (3.6\% in $2017,3.2 \%$ to $3.5 \%$ forecast in 2018$)$. This is relatively high compared with Western economies. In tandem, the real total wages and the real basic wages have grown in line with Singapore GDP from 2012 to 2015, while Singapore's labour productivity exhibits a similar trend as seen in Figure 1. INSERT FIGURE. 1 ABOUT HERE-

The regular deliberations of the tripartite NWC have seen the income of Singapore residents (citizens and permanent residents) increasing along with Singapore's economic performance. It is a formula for wage determination that indeed provides effective wealth distribution, with cumulative change as for $2008-2018$ of $+53.2 \%$ of nominal wages $(+30 \%$ in real wages $)$. In contrast to Western counterparts where wages have been stagnant, the annual labour productivity growth in Singapore has been going hand-in-hand with real wage growth, thanks to some extent to the NWC wage determination system, which functionally provides a basis for some form of built-in institutionalized "trickle-down" economics.

\section{INSERT FIGURE. 2 ABOUT HERE}

The recovery from the GFC was emblematic of Singapore's commitment to human capital, with "a multi-pronged effort to stabilize employment levels supported by a tripartite approach to employment relations" (Waring and Lewer, 2013, p. 221). A Tripartite Guidelines on 
Managing Excess Manpower was issued in November 2008, including temporal flexibility alternatives and a Job Credits scheme designed to save jobs introduced in the 2009 budget (Shanmugaratnam, 2009). These guidelines reflected NTUC Secretary-General Lim Swee Say's sentiment who urged in the 2009 Budget Speech that "businesses should cut costs to save jobs, not cut jobs to save costs" (Le Queux and Waring, 2010, p. 224).

In addition, the Singapore Government introduced the Skills Program for Upgrading and Resilience (SPUR) program at a cost of $\$ 600$ million over two years and providing up to 1000 different courses designed to upgrade a wide variety of workers' skills. Shifting institutional support to HRD, directed at the Singaporean "core" workforce has been implemented since to buckle low-wage and low skills employment.

\section{Harnessing Human Capital: The Legacy of 君子Junzi leadership}

Whether Western theories about leadership fit with the Asian context is debatable (Zhao and Jiang, 2009; Leung, 2012; Pezzutto, 2019) and various studies have attempted to address the particularism of the Asian context (Jung and Avolio, 1999; Walumbwa and Lawler, 2003; Taormina and Selvarajah, 2005; Miao et al 2012; Pezzutto, 2019). Moreover, in a highcontext culture generally found in Asia, there are many contextual elements that help people to understand the rules and much is taken for granted (Hall and Hall, 1989). This can be very confusing for person who does not understand the 'unwritten rules' of the culture. It may appear, for example, that governance in Singapore displays concrete illustrations of both forms of transactional and transformational leadership, as per Bass's (1996) typology. It may also be tempting to look at Lee Kuan Yew's transformative influence in shaping Singapore with the lens of the 'Great Man' theory, as so many biographers did. Rather, it is observed that considering Confucianism as a value system contribute to better understanding leadership in the Asian context, and Singapore notably. 
Gong and Jang (1998) characterized the cultures of East Asia, including Singapore, as "neoConfucian" and thus rooted in the Confucian teaching tradition. The Confucian revival or New Confucianism conveys a discourse of inheritance and continuation of Asian values. At the heart of this discourse lay an emphasis on cultural relativism and the claim that liberal democracy and the mainstream human rights agenda were Western cultural norms that did not belong in Asia (Pezzutto, 2019). This discourse was particularly popular throughout the 1980s and 1990s, which saw Singapore emerge as an intellectual centre of a transnational Confucian revival with the opening the Institute for East Asian Philosophies in 1983 and a number of international conferences on Confucian thought hosted in Singapore (Makeham, 2008, p. 23).

Singapore's success story owes much to its leaders, and notoriously Mr. Lee Kuan Yew. Amrine (2013) suggested that Singaporeans would not be where they are today if it was not for these values. Lee Kuan Yew frequently heralded "Confucian values" as the key factor in the country's rapid capitalist modernization. Lee himself was a self-confessed Confucianist, which had deep value-based implications in the way he led Singapore. Lee Kuan Yew noted: "I am not bound by theories, but my upbringing in a three-generation family made me an unconscious Confucianist. It steeps into you, the Confucianist belief that society works best where every man aims to be a gentleman. The ideal is a Junzi, a gentleman" (Plate, 2013, p. 177).

Confucian Junzi (gentleman) sought grace and dignity by fulfilling traditional obligations: "Confucian rationalism meant rational adjustment to the world" (Weber, 1968, p. 248). Junzi leadership is envisioned to possess overlapping attributes balancing both a moral person and a leader (Trevino et al., 2000; Trevino and Brown, 2007), by matching one's words with his/her deeds or actions, thereby serving as a good role model for others to follow. It is the defining symbol of the ultimate virtuous person and is the personification of the Confucian 
moral core - Ren, $Y i$, and $L i$. Ren is a human capacity of compassion or benevolence for fellow human beings. $Y i$ is a sense of moral rightness with the capacity to discern appropriateness through one's acts and relationships. $L i$ represents etiquettes, norms, and protocols in dealing with personal and institutional lives.

A complete review of Confucianism lies beyond the remit of this paper, though key conceptual notifications are needed to contextualize the discussion. At a broad level, Confucian political philosophy is an open system that is founded on the basis of a humanist concern for people and the moral idealism of self-cultivation (Cheng, 2011). Confucian values may refer to a number of things, including, but not limited to, the valuing of education, discipline, thriftiness, hierarchy, self-reliance, harmony, the centrality of the family, morality, self-cultivation and peace (Tu, 1984; Koh, 2000; Barr, 2000; Makeham, 2008; Chia, 2015).

Confucianism principles insist upon centralized authority, hierarchical order, harmony, diligence and hard work, seniority-based reward systems, and paternalistic management, which have been observed as common features in Chinese organizations (Taormina and Selvarajah, 2005; Pun, Chin and Lau, 2000) and have deep ramifications in Chinese industrial relations (Laulusa, 2008). As noted by Fu and Tsui (2003, p. 425), "Chinese business leaders all over the world are known to exhibit an extreme high degree of authoritarianism while also showing benevolence to subordinates and demonstrating a high level of moral character in their actions and decisions reflecting the influence of the deeply embedded Confucian values". Likewise, Rarick (2009) note some common characteristics of the Chinese approach to organizational management, such as centralised control, collectivism, authoritarian and paternalistic leadership, and the primacy of the hierarchical family model would be concepts that are largely an anathema to the Western liberal individualism. In their discussion of Chinese leadership, McElhatton and Jackson (2012) highlight that an impediment to properly comprehending the Chinese model of leadership is the West's approach to the notions of 
paternalism or authoritarianism. Indeed, Singapore, alike other neighboring countries such as South Korea and Taiwan has often been labelled as a 'soft authoritarian' regime by Western observers (Johnson, 2002, in McCann, 2014, p. 289), yet also by Asian critics (Ng, 2018).

Confucian leadership style or Junzi has been presented as a form of transformational leadership (Wong, 2013). Ip (2011, p. 692) describes a Junzi as a moral person who "would possess and demonstrate his genuine care and concern toward people, and would be committed to do the right thing in both personal and professional lives." Confucius symbolizes leaders as "authentic idealized influence" (Bass \& Steidlmeier, 1999), hence Junzi as a moral exemplar. Constantly, Confucius himself reminded his students to establish themselves, at the same time, to establish others. In sum, the commitment to, and the exercise of, Ren, $Y i$ and $L i$ virtues constitute the core of Junzi leadership (Ip, 2011).

Lee Kuan Yew's Confucian ethos has been widely acknowledged, also in the way he conceived governance in Singapore. Barr (2000, p. 212) highlights, "at many important levels, Lee Kuan Yew's approach to the personnel of government was unambiguously Confucian (...) Lee's whole notion of an educated elite which is 'groomed to govern' fits comfortably into the Confucian model of mandarinate." Chua Beng Huat (cited in Barr 2000, pp. 212-213) once remarked that the PAP leadership “... may be said to have 'Confucianized' itself by prescribing for itself a code of ethics, that of junzi” (...) setting themselves up "as a model of a moral leadership which governs in the interest of the people rather through self-interest."

The PAP enshrined Confucian values as a part of Singapore's national ideology. In 1991, the Parliament of Singapore passed the "White Paper on Shared Values", which clearly emphasized the centrality of Confucianism teachings in Singapore (Pezzutto, 2019). Shortly thereafter, civics and moral education classes in the national school curriculum drew heavily 
on the idea of Shared Values and was introduced as a subject (Chia, 2015). Confucian leadership, the moral imperatives of benevolence (Ren) and obedience, have arguably contributed to shaping Singapore's models of economic development and HRD. Of significance too, the quest for self-development inherent to Confucian ethics is providing a holistic conception of human capital. In Confucian Ethics Today - The Singapore Challenge, $\mathrm{Tu}(1984)$ publicly noted that the "main concern of Confucianism is how we learn to be human (...) a highly complex process which involves commitment, continuous effort (...) learning to be human does not simply happen by itself" (p. 4); adding, "the gentleman, a profound person, is not simply a tool or a vessel for the performance of some task (...) the process of learning to be human, then, involves at least self-cultivation, self-mastery, and self-understanding” (p. 8).

From theology down to practice, Confucian principles thus involve a strong work ethic, a discipline up to the leader to demonstrate and harness. Lee Kuan Yew said, "the task of the leaders must be to provide or create for them a strong framework within which they can learn, work hard, be productive and be rewarded accordingly. And this is not easy to achieve" (Lee, 2012). Such a viewpoint formed the building block for reforms toward the productivist agenda in nation-building (Haley et al., 1996), which permeated through the public service and private sector businesses alike. Advocating changes in the labour law in favor of corporations/businesses and departing from British industrial order, Lee Kuan Yew's address to Singaporean unions in 1968 set the tone: "I am asking you to lick the labour movement into shape, cutting out restrictive practices which are no longer relevant and stopping abuse of fringe benefits which leads to lower productivity ... Cut off all these evils. Jack up productivity. Cut out abuse of privileges and create a new image of a thinking, hard-headed movement" (cited in Loh, 2018, p. 24).

\section{From Productivity to Human Capital Development}


With the Confucian ethos, Singapore has focused on its productivity movement for nearly four decades. This can be described in three major stages according to Ohno and Kitaw (2011) in Figure 3. Initially, the focus had been on promoting teamwork and creating a better understanding amongst employers and employees in Singapore (Hong and Lugg, 2015). As Singapore moved to the "action stage" and "ownership stage," the focus shifted to the actual implementation of programs by Singaporean companies and benchmarking their processes against other companies. Throughout these stages, the governance provided contingency rewards through a transactional leadership style to encourage private and public sector participation. At present, national productivity initiatives are administered through a government statutory board called Enterprise Singapore.

INSERT FIGURE. 3 ABOUT HERE-

In the wake of the GFC, Tripartism was further called into play to address waning productivity among Singaporean firms. An Inter-Agency Productivity Taskforce, including the SNEF, was set up to examine the problem of declining productivity in services (MOM, 2011). To address the waning productivity, the Taskforce proposed several initiatives under a new Workforce Development Agency (WDA). Next, a tripartite National Productivity and Continuing Education Council comprising 25 members including several key Ministers and representatives from unions, companies, trade associations, and chambers was established to boost skills and develop a comprehensive system for continuing education and training. INSERT FIGURE. 4 ABOUT HERE-

In a regional comparison, however, Singapore's labour productivity (based on value added per worker) had been sluggish from 2012 to 2016 at between -0.1 and 1.8 percent. Figure 4 indicates the average growth in productivity and wages in Singapore between 2010 and 2016 to be lower levels than countries like Thailand and China, although these countries were in a 
catch-up mode. Southern Asia had a hike in annual productivity growth between 2007 and 2017, at 4.8 percent, which was 0.8 points higher than the 1997-2017 period, and well above the global average of 2.4 percent (ILO, 2018a, p. 2). Productivity growth in Singapore picked up in 2017 to 3.4 percent (MOM, 2018), perhaps an early sign of policy interventions yielding results.

To this end, the Singapore government has introduced a raft of further policy measures to improve Singapore's productivity output. These include (a) curtailing Singapore's dependency on low-skilled foreign labour in certain sectors, (b) providing tax exemptions and incentives to businesses to innovate and embrace the use of technology, and (c) establishing funding mechanisms for Singaporean workforce constantly to upgrade their skills in emerging economies. Echoing the Singapore government's concern, the SNEF undertook the management of a program, SkillsFuture, launched by the WDA in 2014 (MOM, 2019). However, in October 2016, the WDA went through a restructuring exercise and was reconstituted into Workforce Singapore (WSG) and SkillsFuture Singapore (SSG).

\section{Recent Initiatives toward Human Capital Development}

The newly instituted SSG and WSG are complemented by the Tripartite Alliance for Fair and Progressive Employment Practices (TAFEP), set up in 2006, to enable employees to realize their potential and help their employers achieve better organizations in areas such as age management and work-life balance. Importantly, TAFEP also investigates workplace discrimination complaints, to be reported to the MOM when breaches are confirmed. TAFEP's Human Capital Partnership, in particular, allows all firms to access a human capital development advisory service and to identify schemes and grants for human capital development. Work-Life Works! is another key project of TAFEP. It is providing a resource portal to assist employers in the implementation of work-life strategies. 
It was recently announced that these two statutory boards (SSG and WSG) would move the national focus on employment and skills forward in Singapore (Seow, 2016). The SSG, now a statutory board under the Ministry of Education, aims at promoting lifelong learning through the pursuit of skills. SSG integrates adult training infrastructure in Singapore (Committee for Private Education and Institute for Adult Learning) and fosters a culture of continuing education in the country. On the labour front, WSG under the MOM was set up to transform the local workforce and industry to meet ongoing economic challenges. While its key focus is to help workers meet their career aspirations and secure quality jobs at different stages of life, WSG is also set to address the needs of business owners and companies by providing support to enable manpower-lean enterprises. WorkPro, by WSG, encourages progressive employment practices in companies to benefit Singaporeans. Additional grants are available in WorkPro to support companies in job redesign, age management schemes, and to sustain flexible work arrangements. The NTUC and SNEF, under the tripartite arrangements, administer WorkPro schemes. All these measures suggest active engagement on human capital development by the State (and its organs) using tripartite partners in addressing future challenges.

Alongside and in responding to the local population's resentment to the flood of migrant workforce into the Singapore labour market, the government has been promoting the concept of the Singaporean "core" (Kuah et al., 2017). This involves looking after and improving the capabilities of local talents to ensure Singapore's future competitiveness. The MOM also instituted the Fair Consideration Framework (FCF) as part of an effort to shield jobs for the Singaporean "core." The FCF, complemented by the TAFEP, established clear guidelines for companies to consider fairly the hiring of Singaporeans over foreigners. Companies that violate the FCF risk scrutiny from the MOM and privileges given to them to hire foreigners on a work pass may be curtailed. Another policy aimed at cementing the notion of the 
"Singaporean core" is the implementation of SkillsFuture policy which grew to the statutory board, SSG. Through SSG, all Singaporeans, no matter at what stage of their life or career, can access various funding schemes to pay for their skills upgrade courses to help them remain employable in an ever-changing economic landscape.

It must be observed, however, that while human capital development is currently being promoted in Singapore, the tenure of unskilled foreign workers, who make up a third of the workforce, is strictly temporary and as such unskilled and semi-skilled foreign workers are less subject to human capital development. Singapore does celebrate an International Migrants Day, where the NTUC and the SNEF have established a Migrant Workers' Center to facilitate the training of migrant workers and educating them about fair employment practices (Lin, 2011), yet steps to protect or "partially incorporate" foreign workers seem to be at an infant stage (Leggett and Le Queux, 2014).

\section{Discussion}

Lee Kuan Yew has been using the wake of New Confucianism as a building block for his leadership and nation building in a form of 'reverse Orientalism' (Pezzutto, 2019). It provided the ideological and sociological foundations to legitimatize and activate the PAP's power structure, including a state sponsored narrative of elitism and meritocracy (Teo, 2019). From the late 1970s onwards, New Confucianism served as a catalyst for identity building, marked by a "sino-centric nation building narrative" that allowed Lee to "tap into the shared sentiment of 'Chineseness' through the stress of Confucian values" (Pezzutto, 2019, p.232). The value system (New Confucianism) justifies the cohesion of the Tripartite system. To borrow from industrial relations paradigms, the context can be characterized by a strong Pluralism within Unitarism. From a sociological perspective, the system is functionally performing as an actor, hence consequently the capability to activate agencies and diffuse 
policies towards the national agenda and capacity building, which, in the case of Singapore, is much about human capital development.

Lee has widely been heralded as a great leader and being the subject of several although not undisputed historiographies (Ang, 2019). Despite being treated with "scant respect" by the Academe, the spell of the Great Man theory is still hard to break (Mouton, 2019). To avoid this caveat, leadership in Singapore have been examined and contextualized through the lens of governance. Another caveat is to apprehend leadership in terms of a 'closed system' ignoring broader sets of 'relationalities' (Alvesson, 2019); all the more so if we consider, to borrow from the field of cultural studies, that Singapore can be classified as a 'high context' Asian culture, where the emphasis lies on relationships (Hall and Hall, 1989).

Contextualising leadership is thus about focusing on the ruling, the rules and their agencies, instead of the ruler. It helps providing an insider insight of social dynamics and power relations at play.

This constructivist disposition also opens avenues for 'contextualized comparison' (Locke and Thelen, 1995) and creates space for heuristic equivalence and conceptual correspondences allowing to 'think across' or, say differently, for a 'dia-logue' to take François Jullien's viewpoint on board (Jullien, 1995). In the French tradition for instance, from Emile Durkheim to Jean-Daniel Reynaud, rules and actors' agency to the rules (regulation as a process) have been central to social explanation, including the interplay between meta-representations (ideology or value systems) and intermediate forms of representation.

Singapore could indeed be branded as a model of 'organic solidarity', in Durkheim's terminology. There are several ways to look at it in the case of Singapore. Junzi leadership implies benevolence and therefore a moral injunction for social inclusion and the need to lay 
foundations for well-being and self-development, not forgetting that it reciprocally involves mutual responsibilities, hence subordination and discipline, including one's moral obligation to become a better person to the limits of their capacity. This is where the politics and economics of human capital meets an ethics, or in critical terms, an internalization of control. Back to Durkheim: rules are constraints. Then too, social cohesion is essential because it is functionally what makes the coherence between the system and the value system. Yet, as coined elsewhere by Richard Hyman, the boundaries of inclusion are also the frontiers of exclusion (Hyman, 1999). Hence heightened local concerns over the expansion of the migrant workforce aside the so-called Singaporean 'core'.

Exploring further correspondences are beyond the scope of this paper and would perhaps be more adequately debated in regards to industrial relations: e.g. the quasi absence of industrial conflict, industrial democracy under 'ultra-corporatism' and blurring lines between collectivism and individualism. However, we share the view that looking at the social foundations of governance can lead to a multi-layered and more nuanced examination of leadership. In essence, to recap the argument, harnessing manpower is vital to Singapore and Tripartism has long been pivotal to HRD strategies (Osman Gani and Tan, 1998, p. 418, 421). Human capital is existential to Singapore both as an economic and moral imperative. Leadership in Singapore can be usefully comprehended by looking at how governance has been set up to meet those two imperatives intertwining a system and a value system in a tight knit manner.

\section{Conclusion}

Tripartism in Singapore differs from European-style corporatisms, through which government agencies relayed by social partners orchestrate and diffuse their policy, often as a facilitative tool. Indeed, policy diffusion in Singapore happens rapidly because of closely 
knitted relationships, cooperation and collaborations between the tripartite actors arguably producing "faster, deeper, more effective transmission of state policy" as pointed out by Sheldon et al. (2015, p. 441).

With the recent focus on skills upgrade, the NTUC and SNEF are all geared-up to encourage workers to take advantage of the various government training grants. Employers, unions, education, and training providers are all guided by the direction set forth by the high-level Council for Skills, Innovation and Productivity, which is currently chaired by the Deputy Prime Minister, Mr. Tharman Shanmugaratnam. In keeping with Singapore's tripartite labour management system, the SkillsFuture Council was established as a tripartite body that, in the view of the MOM, is expected to "coordinate and drive a national effort to help Singaporeans develop skills relevant to the future, and build a future based on the mastery of skills in every job” (MOM, 2019).

Under the same initiative, SkillsFuture has identified certain sectors to focus on boosting national productivity. Further, an Industry Transformation Map across 23 sectors is being used under an Industrial Transformation Policy fostering new business models with the objective to retain talent and to deepen skills to increase value addition in an approach designed to meet each sector-specific need. As observed by Sakamoto and Sung (2018, p. 15): "the most useful insight from the Singapore approach is the need for a highly balanced approach that involves both the demand for higher and new skills as well as the supply to meet the new demand". However, although job quality and upskilling are important policy outcomes, productivity remains the primary concern in the mix: "raising productivity is not just our most important priority but enables us to build a better society. Higher productivity is the only sustainable way to raise incomes for ordinary Singaporeans, and provide jobs that give people a sense of responsibility and empowerment" (Shanmugaratnam, 2013, cited in Bali et al., 2019, p. 1). 
Yet, evidence still suggests that labour foreign inbound has so far provided and continues to provide the primary input for economic growth. As one prominent observer was to comment in a discussion in late 2018: "employers are still on steroids with migrant labour." The Singapore government is aware that the volume of labour and associated migration has become a social dilemma. Hence, the productivity and skills formation agenda is getting even more central to governance. Interviewed in 2015, the MOM actually confirmed that the tightening of the labour market through restrictions of employment passes was to pressure the demand side to seek innovative ways to achieve productivity gains instead.

The 2018 ILO report on Skills and the Future of Work: Strategies for Inclusive Growth in Asia and the Pacific stated that if "serious about achieving inclusive growth, there is more than just the demand and supply of skills to deal with. Policy must address the challenges of transition, such as identifying barriers and ensuring steady progress. These challenges mean that adjustments should be treated as societal and institutional and are not just coming from individuals" (Sakamoto and Sung, 2018, p. 16). It is thus a matter of governance. And indeed, how the SkillsFuture has been used to address upskilling is a demonstration of system-based leadership and coordination in policy-making.

Such an institutional approach in management development, we have observed, is embedded into the Singaporean model of governance and is intrinsic to the Confucian Junzi leadership that inspired Singaporean leaders and their commitment toward human capital development. Singapore is leading human capital development by example, and it will be interesting to assess how policies and social mechanism put in place and best practices, still a work-inprogress, can set a benchmark for the ASEAN, especially within Singapore's renewed Partnership Agreement with the ILO (ILO, 2018b) to promote Decent Work and contribute to the achievement of the Sustainable Development Goals in Asia. 


\section{References}

Alvesson, M. (2019), "Waiting for Godot: Eight major problems in the odd field of leadership studies", Leadership, Vol. 15((1)), pp. 27-43.

Amrine, D. (2013), The wit \& wisdom of Lee Kuan Yew [1923-2015], Didier Millet, Singapore Editions.

Ang, C.G. (2019), "Biography and history: The historiography of Lee Kuan Yew”, Asian Studies Review, Vol. 43(3), pp. 544-561.

Armstrong, K.A. (2012), "EU social policy and the governance architecture of Europe 2020", Transfer: European Review of Labour and Research, Vol. 18 No. 3, pp. 285-300.

Bali, A., McKiernan, P., Vas, C. and Waring, O. (2019), Productivity and Innovation in SMEs : Creating Competitive Advantage in Singapore and South East Asia, Routledge Focus on Environment and Sustainability, Routledge, Abingdon, Oxon.

Barr, M.D. (2000), Lee Kuan Yew. The Beliefs Behind the Man, Curzon Press, Richmond, Surrey.

Bass, B. M. and Steidlmeier, P. (1999), "Ethics, character, and authentic transformational leadership behaviour", The Leadership Quarterly, Vol. 10 No. 2, pp. 181-217.

Bass, B.M. (1996), "Is there universality in the full range model of leadership?", International Journal of Public Administration, Vol. 19 No. 6, pp 731 - 761

Cheng, C. (2011), "Confucian global leadership in Chinese tradition: classical and contemporary", Journal of Management Development, Vol. 30 No. 7/8, pp. 647-662.

Coe, N.M. and Kelly, P.F. (2000), "Distance and discourse in the local labour market: The case of Singapore", Area, Vol. 32 No. 4, pp. 413-422.

Fu, P. and Tsui, A. (2003), "Utilizing printed media to understand desired leadership attributes in the People's Republic of China”, Asia Pacific Journal of Management, Vol. 20 No. 4, pp. 423-446.

Gong, Y. and Jang, W. (1998), "Culture and development: reassessing cultural explanations on Asian economic development”, Development and Society, Vol. 27 No. 1, pp. $77-$ 97.

Haley, U.C.V., Low, L. and Toh, M.H. (1996), "Singapore Incorporated: reinterpreting Singapore's business environments through a corporate metaphor", Management Decision, Vol. 34 No. 9, pp. 17-28.

Hall, E. T. and Hall, M. R. (1989), Understanding cultural differences. Intercultural press.

Hong, M.T. and Lugg, A. (2015), The Rise of Singapore (2-Volume Set), World Scientific, Singapore. 
Hyman, R. (1999), “Imagined Solidarities: Can Trade Unions Resist Globalization?” in P. Leisink (Eed.), Globalization and Labour Relations, Cheltenham: Edward Elgar, Cheltenham, pp. 94-115.

International Labour Organisation (2018b), "ILO and Singapore moving forward to promote decent work in Southeast Asia", available at https://www.ilo.org/asia/mediacentre/news/WCMS_631487/lang--en/index.htm (accessed 19 Jan 2019).

International Labour Organization (2018a), “Asia-Pacific employment and social outlook 2018”, available at https://www.ilo.org/wcmsp5/groups/public/---asia/---robangkok/---sro-bangkok/documents/publication/wcms_649885.pdf (accessed $19 \mathrm{Jan}$ 2019).

Ip, P.K. (2011), "Practical wisdom of Confucian ethical leadership: a critical inquiry", Journal of Management Development, Vol. 30 (7/8), pp. 685-696.

Jullien, F. (1995), Le Détour et l'Accès. Stratégies du sens en Chine, en Grèce, Grasset. Translated as Detour and Access: Strategies of Meaning in China and Greece, MIT Press, 2004.

Jung, D.I. and Avolio, B.J. (2000), “Opening the black box: An experimental investigation of the mediating effects of trust and value congruence on transformational and transactional leadership", . Journal of Organizational Behavior, Vol 21(8), 949-964.

Kuah A.T.H., Le Queux, S. and Hassan, S. (2017), "L'ultra-corporatisme au service du Singaporean Core", Chronique Internationale de l'IRES, Vol. 156, pp. 60-74.

Laulusa, L. (2008), "Confucianism and its implications for industrial relations in China", Journal of Management Spirituality and Religion, 2008, Vol. 5 No. 4, pp.385-403.

Le Queux, S., and Waring, P. (2010), “Australie/Singapour: deux exemples de résilience à la crise", Chronique Internationale de l'IRES, No 127, pp 222-230.

Lee, K.Y. (2012), The Singapore Story: Memoirs of Lee Kuan Yew (Vol. 1), Marshall Cavendish, International Asia, Singapore.

Leggett, C. (2013), "Workforce development and skills formation in Singapore”, in Benson, J., Gospel, H. and Zhu, Y. (Eds) Workforce Development and Skill Formation in Asia. Routledge Studies in the Growth Economies of Asia, Routledge, London, pp. 89-114.

Leggett, C. and Le Queux, S. (2014), “Unions as agency of migrant workers' discrimination and social exclusion", in New Frontiers for Citizenship at Work, CRIMT 2014 International Conference, 12-14 May.

Leggett, C., Kuah, A.T.H. and Gan, B. (2017), “Employers' associations in Singapore: Tripartite engagement', in Benson, J., Zhu, Y. and Gospel, H. (Eds), Employers' Associations in Asia: Strategy and Structure, Routledge, England, pp. 96-115. 
Leung, K. (2012), "Indigenous Chinese management research: like it or not, we need it", Management and Organization Review, Vol. 8 No. 1, pp. 1-5.

Lin, W. (2011), "Foreign workers should get training too", Straits Times, 9 September, Singapore Press Holdings, Singapore.

Locke, R.M. and Thelen, K. (1995), “Apples and oranges revisited: Contextualized comparisons and the study of comparative labor politics", Politics \& Society, Vol. 23(3), pp. 337-367.

Loh, O.H. (2018), Industrial Relations in Singapore: Practice and Perspective, Align Group, World Scientific, Singapore.

Makeham, J. (2008), Lost soul: “Confucianism” in contemporary Chinese academic discourse. Harvard University Press, Cambridge, MA.

McCann, L. (2014), International and Comparative Business. Foundations of Political Economies, Sage, London.

McElhatton, E. and Jackson, B. (2012), "Paradox in harmony: Formulating a Chinese model of leadership". Leadership, Vol 8(4), 441-461.

Miao, Q., Newman, A. and Lamb, P. (2012), “Transformational leadership and the work outcomes of Chinese migrant workers: The mediating effects of identification with leader", Leadership, Vol 8(4), 377-395.

Ministry of Manpower (2001), Human Capital: Ministry of Manpower Annual Report 2001, Ministry of Manpower, Singapore.

Ministry of Manpower (2018), "Singapore yearbook of manpower statistics 2018", available at https://stats.mom.gov.sg/Pages/Singapore-Yearbook-Of-Manpower-Statistics2018-Key-Economic-Indicator.aspx (accessed 19 Jan 2019).

Ministry of Manpower (2019), "SkillsFuture”, available at https://www.mom.gov.sg/employment-practices/skills-training-anddevelopment/skillsfuture (accessed 19 Jan 2019).

Mouton, N. (2019), “A literary perspective on the limits of leadership: Tolstoy's critique of the great man theory", Leadership, Vol. 15(1), pp. 81-102.

Ng, H-Y. (2018), "Decentralised Institutions and Electoral Authoritarianism: The Case of Town Councils in Singapore", Asian Studies Review, Vol. 42 No. 3, pp. 469-478.

Ohno, I. and Kitaw, D. (2011), "Productivity movement in Singapore", Kaizen National Movement: A Study of Quality and Productivity Improvement in Asia and Africa, JICA-GRIPS, Tokyo, pp. 49-68.

Osman-Gani, A.M. and Tan, W.L. (1998), "Human resource development: the key to sustainable growth and competitiveness of Singapore", Human Resource Development International, Vol. 1(4), pp. 417-432 
Pezzutto, S. (2019), "Confucianism and capitalist development: From Max Weber and Orientalism to Lee Kuan Yew and New Confucianism", Asian Studies Review, Vol 43(:2), pp. 224-238.

Plate, T. (2013), Giants of Asia: Conversations with Lee Kuan Yew: Citizen Singapore: How to build a nation, Marshall Cavendish International Asia, Singapore.

Pun, K. F., Chin, K. S., and Lau, H. (2000), “A review of the Chinese cultural influences on Chinese enterprise management", International Journal of Management Reviews, Vol. 2 No. 4, pp. 325-338.

Rarick, C.A. (2009), The historical roots of Chinese cultural values and managerial practices. Journal of International Business Research, Vol 8, pp. 59-66.

Scott, J. (1990), A Matter of Record: Documentary sources in social research, Polity Press, Cambridge.

Seow, J. (2016), "Two new statutory boards set up to oversee skills and employment", Straits Times, 12 January, Singapore Press Holdings, Singapore.

Shanmugaratnam, T. (2009), "Keeping Jobs, Building For The Future", Speech delivered the Budget Statement for the Financial Year 2009, available at: https://www.mof.gov.sg/Newsroom/Press-Releases/Keeping-Jobs-Building-for-theFuture(accessed 22 Jan 2019).

Sheldon, P., Gan, B. and Morgan, D. (2015), "Making Singapore's tripartism work (faster): the formation of the Singapore National Employers' Federation in 1980", Business History, Vol. 57 No. 3, pp. 438-460.

Silverman, D. (2000), “Analysing talk and text”, in Denzin, N.K. and Lincoln, Y.S. (Eds), Handbook of Qualitative Research, 2nd Ed, SAGE, California, pp. 821-835.

Taormina, R.J. and Selvarajah, C. (2005). Perceptions of leadership excellence in ASEAN nations. Leadership, Vol 1 (3), 299-322.

Teo, T. (2019), "Perceptions of meritocracy in Singapore: Inconsistencies, contestations and biases", Asian Studies Review, Vol. 43(:2), pp. 184-205.

Trevino, L.K. and Brown, M.E. (2007), "Ethical leadership: a developing construct”, in Nelson, D.L. and Cooper, C.L. (Eds), Positive Organizational Behavior, Sage, London, pp. 101-16.

Trevino, L.K., Hartman, L.P. and Brown, M. (2000), "Moral person and moral manager: how executives develop a reputation for ethical leadership", California Management Review, Vol. 42, pp. 128-42.

Tu, W. (1984), Confucian Ethics Today. The Singapore Challenge, Federal Publications, Singapore.

Walumbwa, F.O., Lawler, J.J., Avolio, B.J., Wang, P. and Shi, K. (2005), Transformational leadership and work-related attitudes: The moderating effects of collective and self- 
efficacy across cultures. Journal of Leadership and Organizational Studies, Vol 11 No. (3), p. 2-16.

Waring, P. and Lewer, J. (2013), The global financial crisis, employment relations and the labour market in Singapore and Australia, Asia Pacific Business Review, Vol. 19 No. 2, pp. 217-229.

Weber, M. (1968). The religion of China: Confucianism and Taoism, The Free Press, New York

New York: The Free Press. Wiarda, H.J. (1996), Corporatism and Comparative Politics: The Other Great "Ism", Comparative Politics Series, Routledge, Oxford.

Wong, C.T.N. (2013), Confucian Junzi Leadership: A model of authentic moral transformation for educational leaders, (Doctoral dissertation, Education: Faculty of Education, Simon Fraser University), available at http://summit.sfu.ca/item/12789 (accessed 28 Feb 2019).

World Bank, World Development Indicators (2019), “GDP growth [Data file]”, available at https://data.worldbank.org/indicator/NY.GDP.MKTP.KD.ZG? contextual=default\&1 ocations $=\mathrm{SG}($ accessed 19 Jan 2019).

Zhao, S.M. and Jiang, C.Y. (2009), "Learning by doing: emerging paths of Chinese management research”, Management and Organization Review, Vol. 5 No. 1, pp. 107-119 
Figure 1: Singapore's GDP, GDP growth rate, labour productivity, and real wages

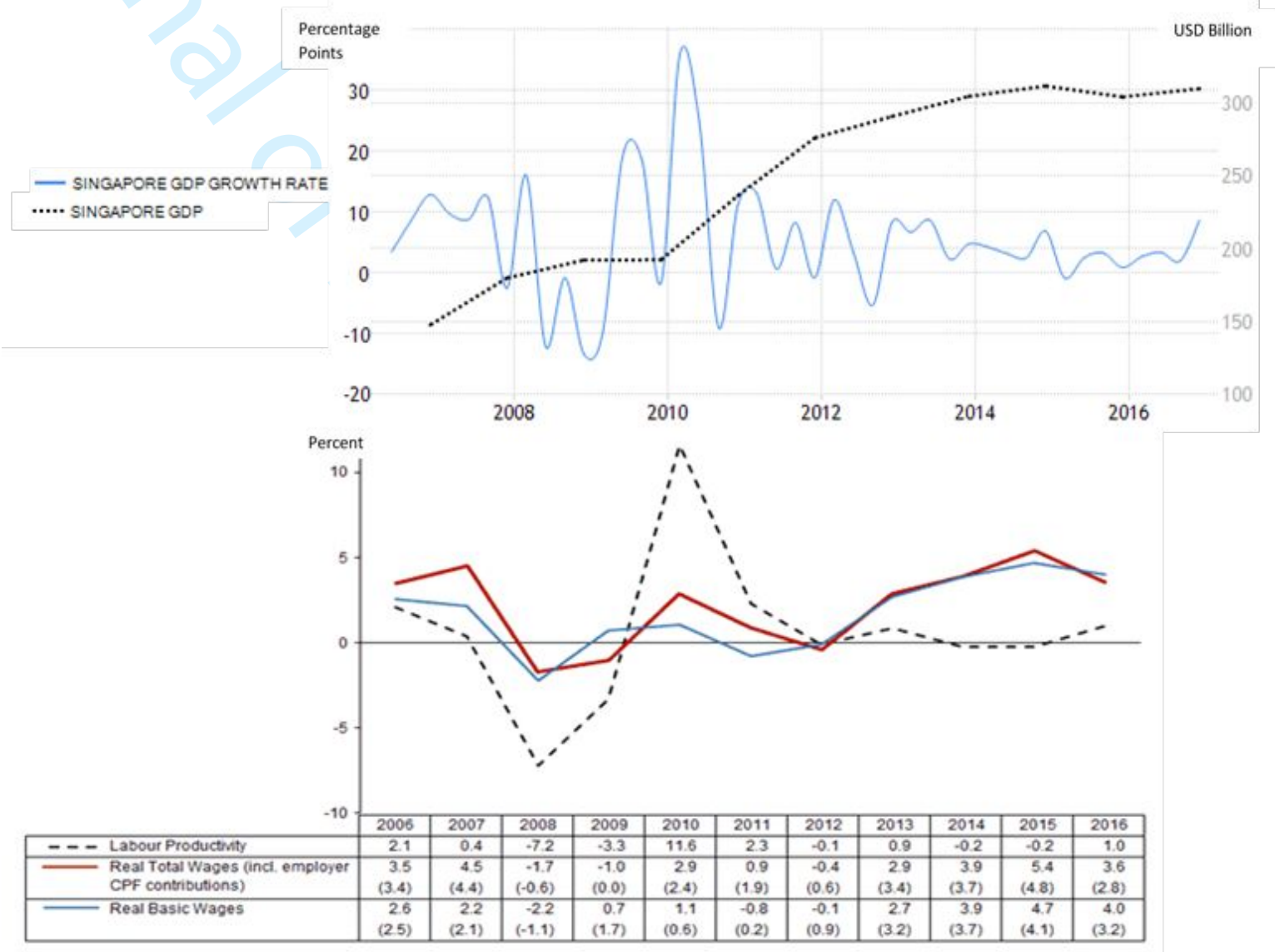

Sources: Survey on Annual Wage Changes, Manpower Research and Statistics Department, Ministry of Manpower; Ministry of Trade and Industry (for Productivity data); and The World Bank (for GDP data) 
Figure 2: Change in Median Gross Monthly Income from Work of Singapore's Residents

\begin{tabular}{|c|c|c|c|c|c|c|}
\hline \multirow[b]{2}{*}{ Mid-Year } & \multicolumn{3}{|c|}{ Annualized Change (\% p.a.) } & \multicolumn{3}{|c|}{ Cumulative Change (\%) } \\
\hline & $\begin{array}{l}2008- \\
2018\end{array}$ & $\begin{array}{l}2008- \\
2013\end{array}$ & $\begin{array}{l}2013- \\
2018\end{array}$ & $\begin{array}{l}2008- \\
2018\end{array}$ & $\begin{array}{l}2008- \\
2013\end{array}$ & $\begin{array}{l}2013- \\
2018\end{array}$ \\
\hline Nominal & $4.4 \%$ & $5.0 \%$ & $3.7 \%$ & $53.2 \%$ & $27.9 \%$ & $19.8 \%$ \\
\hline $\operatorname{Real}^{\wedge}$ & $2.7 \%$ & $1.9 \%$ & $3.5 \%$ & $30.0 \%$ & $9.7 \%$ & $18.7 \%$ \\
\hline
\end{tabular}

Source: Gross Monthly Income From Work - Comprehensive Labour Force Survey, Manpower Research \& Statistics Department, MOM; Latest figures published in: Labour Force in Singapore

\section{Figure 3: Three Stages of Singapore's Productivity Movement}

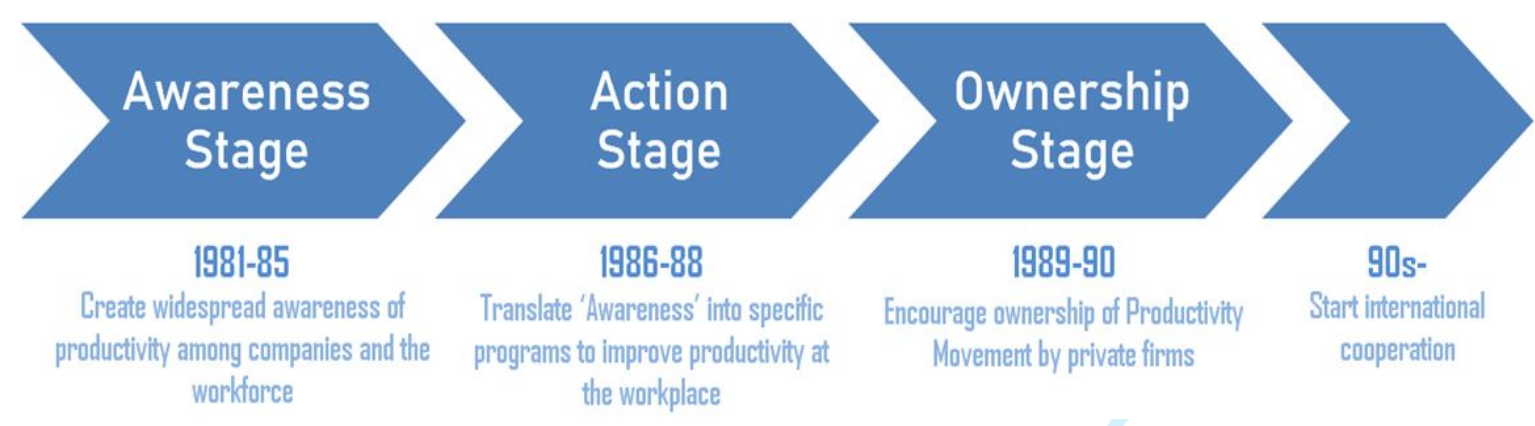

Source: Ohno and Kitaw (2011) 
Figure 4: Average Annual Growth in Wages and Productivity (2010-2016)

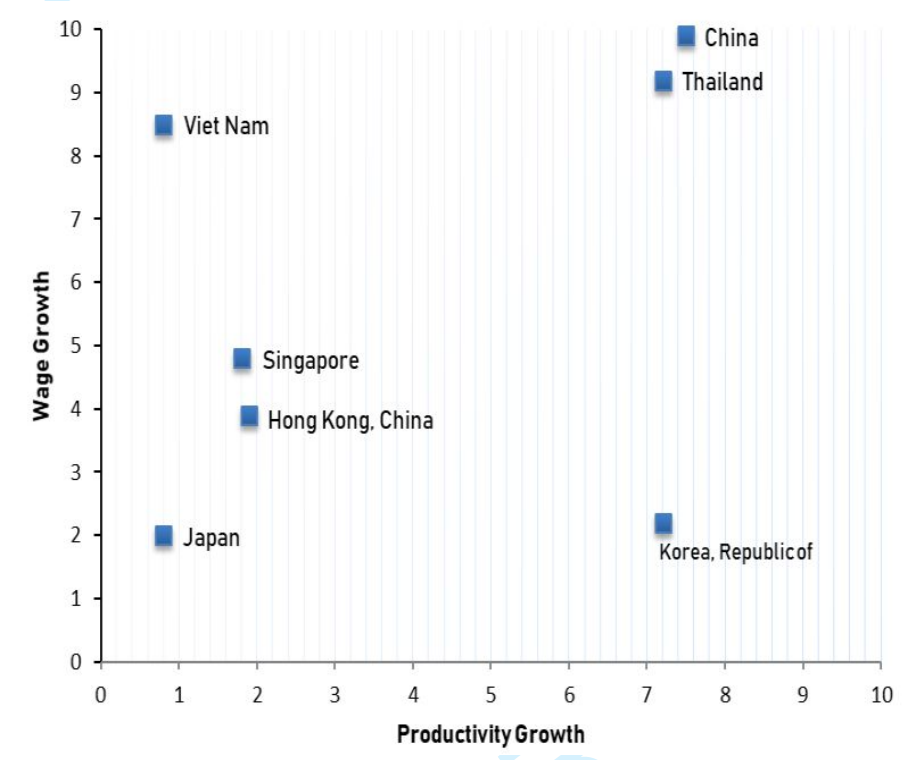

Source: Adapted from ILO, 2018a, p. 4 


\section{君子 Junzi Leadership in Singapore: \\ Governance and Human Capital Development}

\section{Purpose}

This paper provides insights as to how a Confucian inspired Junzi style of leadership translates into initiatives towards human capital development in Singapore. After reviewing tripartite governance in Singapore, we discuss the character of Confucian leadership: how does this value system inform the moral economy of the Singaporean corporatist model and inherently come to impact upon the conception and significance of human capital.

\section{Design/methodology/approach}

The case approach was employed using multiple sources of secondary data, supplemented by interviews with high-profile informants in Singapore. Multiple sources led to data triangulation in presenting a mutually consistent set of evidence. The paper also draws from a longitudinal observation of Singapore's industrial relations and human resource development (HRD) policies over the last 10 years since the Global Financial Crisis.

\section{Findings}

Organized along two thematic areas: governance and human capital development, this paper proposes and finds that governance in Singapore displays an institutionalized form of Junzi leadership that translates into policy-making toward human capital development.

\section{Originality/value}

This paper brings about an Asian perspective of Junzi leadership toward management and governance. The Confucian value system intrinsic to tripartite governance provides an original heuristic lens that help shed a light on the significance of human capital development in Singapore. 


\section{Introduction}

Singapore has a specific form of leadership and governance, a unique brand of 'ultracorporatism' (Kuah et al., 2017), which arguably provides successful policy-making. The virtue of social dialogue at the epicenter of the EU social model has long been heralded yet proved arduous in monitoring its success, thereby leading to the search for a better "governance architecture" (Armstrong, 2012). In contrast, the tripartite governance in Singapore displays dynamic features of agile coordination enabling quick adjustments which bore fruit, as demonstrated by Singapore's sustained economic success.

Tripartite governance is becomes the backbone of Singapore's socioeconomic model, but more importantly, it is labour-centric. The development of human capital is indeed core to Singapore's economic development because of the city-country's lack of natural resources. As stated by Coe and Kelly (2000, p. 414), "there can be few other places in the world where the social regulation of the labour market has been so consistently and explicitly a central component of national development strategy as it has been in Singapore." As such, Singapore is a living laboratory that epitomizes the potential of systemic investment in human capital.

This paper looks at the fabric of tripartite governance, in particular how tripartismTripartism has evolved in Singapore to address challenges facing a-labour shortage challenges, and finally, how tripartite policies are embedded to enhance human capital development (Leggett, 2013). In doing so, discussthe paper discusses how a Confucian ethos or Junzi leadership inspired Singaporean leaders and helpgave ground to-explain the Singaporean model of governance. It is argued that this ethos, in lieu of "political ideology" (Barr, 2000), informs the moral economy underpinning the Singaporean corporatist model.

As a review paper, it does not make an attempt to draw a linear connection between leadership and human capital in the form of a straight relationship between independent and 
dependent variables. Instead, the paper focuses how leadership molds into a model of governance, of which Tripartism is a key institutional feature instrumental to the development of HRD strategies (Osman-Gani and Tan, 1998, p. 421). This is consistent with Miao et al (2012: 391) who suggest that "the main focus of research into Asian leadership $\underline{\text { should be on examining how the mix of cultural and wider contextual influences, such as }}$ particular socioeconomic and industrial contexts, along with particular industrial work dynamics, impact on follower responses to transformational leadership."

The data used in this paper areis informed by a 10-year longitudinal review of Singapore industrial relations and HRD policies between 2009 and 2019. External validation was sought through open-ended interviews with union leaders, directors of employers' associations, directors of closely held government agencies, and a Minister of State for the Ministry of Manpower. Scott's (1990) criteria were used to assess the authenticity, creditability, representativeness, and meaning to information, while Silverman's (2000) technique was used to treat interview data.

The paper is organized along two thematic areas, governance and human capital, as follows: we first review tripartist governance in Singapore and how this has evolved over time to address contemporary and future challenges. Arising from this, we illustrate how this model of governance delivered shared prosperity in delivering both economic and wage growth. Next, we discuss the character of Confucian leadership. Further, we exemplify how such a model of governance and leadership translates into initiatives toward human capital development and may provide a lead for best practices regionally, concluding that considering Confucian value system is a valuable heuristic to understand leadership and governance in Asia and does impact on the meaning and significance of human capital in Singapore. 


\section{The Fabric of Tripartism}

Tripartism refers to an economic corporatism based on tripartite contracts between business, labour, and the State within the economy. Each party acts as a social partner to create an economic policy through cooperation, consultation, negotiation, and compromise (Wiarda, 1996). Tripartism in Singapore is arguably a key reason supporting Singapore's economic advancement into a highly developed trade-oriented economy (Leggett et al., 2017; Kuah et al, 2017). This tripartite arrangement has long been a platform for the Singapore government to launch a wide range of schemes to boost productivity growth, encourage skills upgrading, and even forge consensus on national wage guidelines.

On the one hand, employers' associations and trade union members in Singapore support the government's initiatives to adopt a non-confrontational labour relations practice. All parties involved partake in labour relations and share a belief to work toward an 'amicable and harmonious' outcome that is not disruptive to work. On the other hand, Singapore's political elite adopted the concept of patriarchalism to bolster Singapore's "tripartite arrangements by absorbing key employer interests in building collaborative relationships vital for the developmental state" (Sheldon et al., 2015, pp. 441).

The major players in the Singapore tripartite movement include the Singapore National Employers Federation (SNEF), National Trade Union Congress (NTUC), and Ministry of Manpower (MOM). The formation of the NTUC by the ruling political party (the People's Action Party, or PAP) in 1964 provided the Singapore governmenta strategic thrust to propel its industrial relations initiatives needed due to supply-side bottlenecks andthat led to the government favoring cooperation with labour unions and forging strong alliances with businesses in Singapore (Haley et al., 1996). The unique PAP-NTUC relationship became the core of a wider tripartite system. As a result, itIt has become common to find senior 
officials in public service being seconded into the NTUC to boost the quality and standing of the NTUC leadership. Able union leaders, in turn, are also co-opted into the PAP leadership, fielded as Members of Parliament (MP) and appointed to key offices. Some PAP MPs are tasked to work in the unions to get to know union leaders and members, and their problems, enabling cross-fertilization and knowledge exchanges.

The opportunity to seal the tripartite industrial relations occurred in 1980 when the Ministry of Labour (renamed the Ministry of Manpower-MOM in 1998) effected a merger between the two then largest registered employers' associations (the Singapore Employers' Federation and the National Employers' Council) into the SNEF. The SNEF's ruling Council is made up of 14 representatives from leading companies and multinational corporations in Singapore. The SNEF sets a common agenda on issues such as innovation, productivity, and skills upgrading but still must work within a system where the NTUC-PAP interests have been self-styled as "symbiotic" (Leggett et al., 2017; Loh, 2018, p. 2). The MOM is in charge of orchestrating labour deployment and HRD to meet the needs of companies and multinational corporations in Singapore. Over the years, the MOM has deployed multiple strategies to implement manpower planning, lifelong employability, the augmentation of talent, and the transformation of the work environment (MOM, 2001).

\section{Tripartite Success: Economic and Wage Growth}

To ensure that wage-share grows in tandem with productivity and economic growth in Singapore, a tripartite National Wages Council (NWC) was set up in 1972. Later, in 1979, the PAP adopted a corrective high-wage policy to orchestrate belated economic restructuring. This high-wage policy by the NWC induced a shift in Singapore's economy toward high technology and high value-added production. This $\underline{\text { However, this }}$ required a parallel shift in the management and development of the labour market. The regulatory means for skills 
formation and "character building" were set up by government agencies, the NTUC and the SNEF. Workforce development increasingly became a tripartite endeavor. Leggett, Kuah and Gan (2017) assert that nowhere have Singapore's employers' associations engaged more in tripartite relations than in the centralized wage determination of NWC. In making its recommendations on wage adjustments for the year, the tripartite NWC takes into consideration factors such as productivity growth, employment situation, international competitiveness, and economic growth and prospects.

Singapore successfully made a swift and remarkable recovery from the Global Financial Crisis (GFC) of 2007-2008. After a peak at over 15.24\% average GDP growth across four quarters in 2010 (World Bank, 2019), GDP growth rates have remained relatively steady throughout the rest of the decade (3.6\% in $2017,3.2 \%$ to $3.5 \%$ forecast in 2018$)$. This is relatively high compared with Western economies. In tandem, the real total wages and the real basic wages have grown in line with Singapore GDP from 2012 to 2015, while Singapore's labour productivity exhibits a similar trend as seen in Figure 1. INSERT FIGURE. 1 ABOUT HERE

The regular deliberations of the tripartite NWC have seen the income of Singapore residents (citizens and permanent residents) increasing along with Singapore's economic performance. It is a formula for wage determination that indeed provides effective wealth distribution, with cumulative change as for $2008-2018$ of $+53.2 \%$ of nominal wages $(+30 \%$ in real wages $)$. In contrast to Western counterparts where wages have been stagnant, the annual labour productivity growth in Singapore has been going hand-in-hand with real wage growth, thanks to some extent to the NWC wage determination system, which functionally provides a basis for some form of built-in institutionalized "trickle-down" economics. 
The recovery from the GFC was-alse emblematic of Singapore's commitment to human capital, with "a multi-pronged effort to stabilize employment levels supported by a tripartite approach to employment relations" (Waring and Lewer, 2013, p. 221). A Tripartite Guidelines on Managing Excess Manpower was issued in November 2008, including temporal flexibility alternatives and a Job Credits scheme designed to save jobs introduced in the 2009 budget (Shanmugaratnam, 2009). These guidelines reflected NTUC SecretaryGeneral Lim Swee Say's sentiment who urged in the 2009 Budget Speech that "businesses should cut costs to save jobs, not cut jobs to save costs" (Le Queux and Waring, 2010, p. 224).

In addition, the Singapore Government introduced the Skills Program for Upgrading and Resilience (SPUR) program at a cost of $\$ 600$ million over two years and providing up to 1000 different courses designed to upgrade a wide variety of workers' skills. Shifting institutional support to HRD, directed at the Singaporean "core" workforce has been implemented since to buckle low-wage and low skills employment.

\section{Harnessing Human Capital: The Legacy of 君子Junzi leadership}

Whether Western theories and assumptions-about leadership fit with the Asian context is debatable (Zhao and Jiang, 2009; Leung, 2012; Pezzutto, 2019) and various studies have attempted to address the particularism of the Asian context (Miäet al 2012, Jung and Avolio, 1999; Walumbwa and Lawler, 2003; Taormina and Selvarajah, 2005; Walumbwa and Lawler, 2003):Miao et al 2012; Pezzutto, 2019). Moreover, in a high-context culture generally found in Asia, there are many contextual elements that help people to understand the rules and much is taken for granted (Hall and Hall, 1989). This can be very confusing for person who does not understand the 'unwritten rules' of the culture. It may appear, for example, that governance in Singapore displays concrete illustrations of both forms of 
transactional and transformational leadership, as per Bass's (1996) typology. It may also be tempting to look at Lee Kuan Yew's transformative influence in shaping Singapore with the lens of the 'Great Man' theory, as so many biographers did. Rather, it is observed that considering Confucianism as a value system contribute to better understanding leadership in the Asian context, and Singapore notably.

Gong and Jang (1998) characterized the cultures of East Asia, including Singapore, as "neoConfucian" and thus rooted in the Confucian teaching tradition. The Confucian revival or $\underline{\text { New Confucianism conveys a discourse of inheritance and continuation of Asian values. At }}$ $\underline{\text { the heart of this discourse lay an emphasis on cultural relativism and the claim that liberal }}$ democracy and the mainstream human rights agenda were Western cultural norms that did not belong in Asia (Pezzutto, 2019). This discourse was particularly popular throughout the 1980s and 1990s, which saw Singapore emerge as an intellectual centre of a transnational Confucian revival with the opening the Institute for East Asian Philosophies in 1983 and a number of international conferences on Confucian thought hosted in Singapore (Makeham, 2008, p. 23).

Singapore's success story owes much to its leaders, and notoriously Mr. Lee Kuan Yew. Amrine (2013) suggested that Singaporeans would not be where they are today if it was not for these values. Lee Kuan Yew frequently heralded "Confucian values" as the key factor in the country's rapid capitalist modernization. Lee himself was a self-confessed Confucianist, which had deep value-based implications in the way he led Singapore. Lee Kuan Yew noted: "I am not bound by theories, but my upbringing in a three-generation family made me an unconscious Confucianist. It steeps into you, the Confucianist belief that society works best where every man aims to be a gentleman. The ideal is a Junzi, a gentleman" (Plate, 2013, p. 177). 
Confucian Junzi (gentleman) sought grace and dignity by fulfilling traditional obligations:

"Confucian rationalism meant rational adjustment to the world" (Weber, 1968, p. 248). Junzi leadership is envisioned to possess overlapping attributes balancing both a moral person and a leader (Trevino et al., 2000; Trevino and Brown, 2007), by matching one's words with his/her deeds or actions, thereby serving as a good role model for others to follow. It is the defining symbol of the ultimate virtuous person and is the personification of the Confucian moral core-Ren, $\mathrm{Yi}$, and $\mathrm{Li}$. Ren is a human capacity of compassion or benevolence for fellow human beings. $Y i$ is a sense of moral rightness with the capacity to discern appropriateness through one's acts and relationships. $L i$ represents etiquettes, norms, and protocols in dealing with personal and institutional lives.

A complete review of Confucianism lies beyond the remit of this paper, though key conceptual notifications are needed to contextualize the discussion. At a broad level, Confucian political philosophy is an open system that is founded on the basis of a humanist concern for people and the moral idealism of self-cultivation (Cheng, 2011). Confucian values may refer to a number of things, including, but not limited to, the valuing of education, discipline, thriftiness, hierarchy, self-reliance, harmony, the centrality of the family, morality, self-cultivation and peace (Tu, 1984; Koh, 2000; Barr, 2000; Makeham, 2008; Chia, 2015).

Confucianism reinforcesprinciples insist upon centralized authority, hierarchical order, harmony, diligence and hard work, seniority-based reward systems, and paternalistic management, which have been observed as common features in Chinese organizations (Taormina and Selvarajah, 2005; Pun, Chin and Lau, 2000) and have deep ramifications in Chinese industrial relations (Laulusa, 2008). As-alse noted by Fu and Tsui (2003, p. 425), "Chinese business leaders all over the world are known to exhibit an extreme high degree of authoritarianism while also showing benevolence to subordinates and demonstrating a high level of moral character in their actions and decisions reflecting the influence of the deeply 
embedded Confucian values". Likewise, Rarick (2009) note some common characteristics of the Chinese approach to organizational management, such as centralised control, collectivism, authoritarian and paternalistic leadership, and the primacy of the hierarchical family model would be concepts that are largely an anathema to the Western liberal individualism. In their discussion of Chinese leadership, McElhatton and Jackson (2012) highlight that an impediment to properly comprehending the Chinese model of leadership is the West's approach to the notions of paternalism or authoritarianism. Indeed, Singapore, alike other neighboring countries such as South Korea and Taiwan has often been labelled as a 'soft authoritarian' regime by Western observers (Johnson, 2002, in McCann, 2014, p. 289), yet also by Asian critics ( $\mathrm{Ng}, 2018)$.

Confucian leadership style or Junzi has been presented as a form of transformational leadership (Wong, 2013). Ip (2011, p. 692) describes a Junzi as a moral person who "would possess and demonstrate his genuine care and concern toward people, and would be committed to do the right thing in both personal and professional lives." Confucius symbolizes leaders as "authentic idealized influence" (Bass \& Steidlmeier, 1999), hence Junzi as a moral exemplar. Constantly, Confucius himself reminded his students to establish themselves, at the same time, to establish others. In sum, the commitment to, and the exercise of, Ren, $Y i$ and $L i$ virtues constitute the core of Junzi leadership (Ip, 2011).

Lee Kuan Yew's Confucian ethos has been widely recognizedacknowledged, also in the way he conceived governance in Singapore. Barr (2000, p. 212) highlights, "at many important levels, Lee Kuan Yew's approach to the personnel of government was unambiguously Confucian (...) Lee's whole notion of an educated elite which is 'groomed to govern' fits comfortably into the Confucian model of mandarinate." Chua Beng Huat (cited in Barr 2000, pp. 212-213) once remarked that the PAP leadership “... may be said to have 'Confucianized' itself by prescribing for itself a code of ethics, that of junzi” (...) setting 
themselves up "as a model of a moral leadership which governs in the interest of the people rather through self-interest."

Confucian leadership, the moral imperatives of benevolence (renThe PAP enshrined $\underline{\text { Confucian values as a part of Singapore's national ideology. In 1991, the Parliament of }}$ Singapore passed the "White Paper on Shared Values", which clearly emphasized the centrality of Confucianism teachings in Singapore (Pezzutto, 2019). Shortly thereafter, civics and moral education classes in the national school curriculum drew heavily on the idea of $\underline{\text { Shared Values and was introduced as a subject (Chia, 2015). Confucian leadership, the moral }}$ imperatives of benevolence (Ren) and obedience, have arguably contributed to shaping Singapore's models of economic development and HRD. Of significance too, the quest for self-development inherent to Confucian ethics is providing a holistic conception of human capital. In Confucian Ethics Today - The Singapore Challenge, Tu (1984) publicly noted that the "main concern of Confucianism is how we learn to be human (...) a highly complex process which involves commitment, continuous effort (...) learning to be human does not simply happen by itself" (p. 4); adding, "the gentleman, a profound person, is not simply a tool or a vessel for the performance of some task (...) the process of learning to be human, then, involves at least self-cultivation, self-mastery, and self-understanding” (p. 8).

From theology down to practice, Confucian ethiesprinciples thus involve a strong work ethic, a discipline up to the leader to demonstrate and harness. Lee Kuan Yew was then to saysaid, "the task of the leaders must be to provide or create for them a strong framework within which they can learn, work hard, be productive and be rewarded accordingly. And this is not easy to achieve" (Lee, 2012). Such a viewpoint formed the building block for reforms toward the productivist agenda andin nation-building (Haley et al., 1996) that translate inte), which permeated through the public service and private sector businesses alike. Advocating changes in the labour law in favor of corporations/businesses and departing from British industrial 
order, Lee Kuan Yew's address to Singaporean unions in 1968 set the tone: "I am asking you to lick the labour movement into shape, cutting out restrictive practices which are no longer relevant and stopping abuse of fringe benefits which leads to lower productivity ... Cut off all these evils. Jack up productivity. Cut out abuse of privileges and create a new image of a thinking, hard-headed movement" (cited in Loh, 2018, p. 24).

\section{From Productivity to Human Capital Development}

With the Confucian ethos, Singapore has focused on its productivity movement for nearly four decades, which. This can be described in three major stages according to Ohno and Kitaw (2011) in Figure 3. Initially, the focus had been on promoting teamwork and creating a better understanding amongst employers and employees in Singapore (Hong and Lugg, 2015). As Singapore moved to the "action stage" and "ownership stage," the focus shifted to the actual implementation of programs by Singaporean companies and benchmarking their processes against other companies. Throughout these stages, the Singapore governmentgovernance provided contingency rewards, through a transactional leadership style, to encourage private and public sector erganizations to participate activelyparticipation. At present, national productivity initiatives are administered through a government statutory board called Enterprise Singapore.

\section{INSERT FIGURE. 3 ABOUT HERE}

In the wake of the GFC, tripartism Tripartism was further called into play to took intoaddress waning productivity among Singaporean firms. An Inter-Agency Productivity Taskforce, including the SNEF, was set up to examine the problem of declining productivity in services (MOM, 2011). To address the waning productivityin companies and the nation, the Taskforce proposed several initiatives under a new Workforce Development Agency (WDA). Next, a tripartite National Productivity and Continuing Education Council comprising 25 
$\underline{\text { members including several key Ministers and representatives from unions, companies, trade }}$ associations, and chambers was established to boost skills and develop a comprehensive system for continuing education and training. The Council comprises 25 members including several key Ministers, representatives from unions, companies, trade associations, and ehambers.

INSERT FIGURE. 4 ABOUT HERE-

In a regional comparison, however, Singapore's labour productivity (based on value added per worker) hashad been sluggish from 2012 to 2016 at between -0.1 and 1.8 percent. Figure 4 indicates the average growth in productivity and wages in Singapore between 2010 and 2016 to be lower levels than countries like Thailand and China, although these countries were in a catch-up mode. Southern Asia had a hike in annual productivity growth between 2007 and 2017 , at 4.8 percent, which was 0.8 points higher than the $1997-2017$ period, and well above the global average of 2.4 percent (ILO, 2018a, p. 2). Productivity growth in Singapore picked up in 2017 to 3.4 percent (MOM, 2018), perhaps an early sign of policy interventions yielding results.

To this end, the Singapore government has introduced a raft of further policy measures to improve Singapore's productivity output. These include (a) curtailing Singapore's dependency on low-skilled foreign labour in certain sectors, (b) providing tax exemptions and incentives to businesses to innovate and embrace the use of technology, and (c) establishing funding mechanisms for Singaporean workforce constantly to upgrade their skills in emerging economies. Echoing the Singapore government's concern, the SNEF undertook the management of a program, SkillsFuture, launched by the WDA in 2014 (MOM, 2019). However, in October 2016, the WDA went through a restructuring exercise and was 
reconstituted into Workforce Singapore (WSG) and SkillsFuture Singapore (SSG), to be examined below.).

\section{Recent Initiatives toward Human Capital Development}

The SSG and WSG are two contemporary statutory boards of the Singapore government pivotal to human capital development in Singapore. They The newly instituted SSG and WSG are complemented by the Tripartite Alliance for Fair and Progressive Employment Practices (TAFEP), set up in 2006, to enable employees to realize their potential and help their employers achieve better organizations in areas such as age management and work-life balance. Importantly, TAFEP also investigates workplace discrimination complaints, to be reported to the MOM when breaches are confirmed. TAFEP's Human Capital Partnership, in particular, allows all firms to access a human capital development advisory service and to identify schemes and grants for human capital development. Work-Life Works! is another key project of TAFEP. It is providing a resource portal to assist employers in the implementation of work-life strategies.

It was recently announced that these two statutory boards (SSG and WSG) would move the national focus on employment and skills forward in Singapore (Seow, 2016). The SSG, now a statutory board under the Ministry of Education, aims at promoting lifelong learning through the pursuit of skills. SSG integrates adult training infrastructure in Singapore (Committee for Private Education and Institute for Adult Learning) and fosters a culture of continuing education in the country. On the labour front, WSG under the MOM was set up to transform the local workforce and industry to meet ongoing economic challenges. While its key focus is to help workers meet their career aspirations and secure quality jobs at different stages of life, WSG is also set to address the needs of business owners and companies by providing support to enable manpower-lean enterprises. WorkPro, by WSG, encourages 
progressive employment practices in companies to benefit Singaporeans. Grants Additional grants are available in WorkPro to support companies in job redesign, age management schemes, and to sustain flexible work arrangements. The NTUC and SNEF, under the tripartite arrangements, administer WorkPro schemes. All these measures suggest active engagement on human capital development by the State and strong collaboration between the(and its organs) using tripartite partners in addressing future challenges.

Alongside and in responding to the local population's resentment to the flood of migrant workforce into the Singapore labour market, the government has been promoting the concept of the Singaporean "core" (Kuah et al., 2017). This involves looking after and improving the capabilities of local talents to ensure Singapore's future competitiveness. The MOM also instituted the Fair Consideration Framework (FCF) as part of an effort to shield jobs for the Singaporean "core." The FCF, complemented by the TAFEP, established clear guidelines for companies to consider fairly the hiring of Singaporeans over foreigners. Companies that violate the FCF risk scrutiny from the MOM and privileges given to them to hire foreigners on a work pass may be curtailed. Another policy aimed at cementing the notion of the "Singaporean core" is the implementation of SkillsFuture policy which grew to the statutory board, SSG. Through SSG, all Singaporeans, no matter at what stage of their life or career, can access various funding schemes to pay for their skills upgrade courses to help them remain employable in an ever-changing economic landscape.

It must be observed, however, that while human capital development is currently being promoted in Singapore, the tenure of unskilled foreign workers, who make up a third of the workforce, is strictly temporary and as such unskilled and semi-skilled foreign workers are less subject to human capital development. Singapore does celebrate an International Migrants Day, where the NTUC and the SNEF have established a Migrant Workers' Center to facilitate the training of migrant workers and educating them about fair employment 
practices (Lin, 2011), yet steps to protect or "partially incorporate" foreign workers seem to be at an infant stage (Leggett and Le Queux, 2014).

\section{Discussion and}

Lee Kuan Yew has been using the wake of New Confucianism as a building block for his $\underline{\text { leadership and nation building in a form of 'reverse Orientalism' (Pezzutto, 2019). It }}$ provided the ideological and sociological foundations to legitimatize and activate the PAP's power structure, including a state sponsored narrative of elitism and meritocracy (Teo, 2019). From the late 1970s onwards, New Confucianism served as a catalyst for identity building, marked by a "sino-centric nation building narrative" that allowed Lee to "tap into the shared sentiment of 'Chineseness' through the stress of Confucian values" (Pezzutto, 2019, p.232).

The value system (New Confucianism) justifies the cohesion of the Tripartite system. To borrow from industrial relations paradigms, the context can be characterized by a strong Pluralism within Unitarism. From a sociological perspective, the system is functionally performing as an actor, hence consequently the capability to activate agencies and diffuse policies towards the national agenda and capacity building, which, in the case of Singapore, is much about human capital development.

Lee has widely been heralded as a great leader and being the subject of several although not undisputed historiographies (Ang, 2019). Despite being treated with "scant respect" by the Academe, the spell of the Great Man theory is still hard to break (Mouton, 2019). To avoid $\underline{\text { this caveat, leadership in Singapore have been examined and contextualized through the lens }}$ of governance. Another caveat is to apprehend leadership in terms of a 'closed system' ignoring broader sets of 'relationalities' (Alvesson, 2019); all the more so if we consider, to borrow from the field of cultural studies, that Singapore can be classified as a 'high context' Asian culture, where the emphasis lies on relationships (Hall and Hall, 1989). 
Contextualising leadership is thus about focusing on the ruling, the rules and their agencies, instead of the ruler. It helps providing an insider insight of social dynamics and power relations at play.

This constructivist disposition also opens avenues for 'contextualized comparison' (Locke and Thelen, 1995) and creates space for heuristic equivalence and conceptual correspondences allowing to 'think across' or, say differently, for a 'dia-logue' to take François Jullien's viewpoint on board (Jullien, 1995). In the French tradition for instance, from Emile Durkheim to Jean-Daniel Reynaud, rules and actors' agency to the rules (regulation as a process) have been central to social explanation, including the interplay $\underline{\text { between meta-representations (ideology or value systems) and intermediate forms of }}$ representation.

$\underline{\text { Singapore could indeed be branded as a model of 'organic solidarity', in Durkheim's }}$ terminology. There are several ways to look at it in the case of Singapore. Junzi leadership implies benevolence and therefore a moral injunction for social inclusion and the need to lay foundations for well-being and self-development, not forgetting that it reciprocally involves $\underline{\text { mutual responsibilities, hence subordination and discipline, including one's moral obligation }}$ to become a better person to the limits of their capacity.. This is where the politics and economics of human capital meets an ethics, or in critical terms, an internalization of control. Back to Durkheim: rules are constraints. Then too, social cohesion is essential because it is functionally what makes the coherence between the system and the value system. Yet, as coined elsewhere by Richard Hyman, the boundaries of inclusion are also the frontiers of exclusion (Hyman, 1999). Hence heightened local concerns over the expansion of the migrant workforce aside the so-called Singaporean 'core'. 
Exploring further correspondences are beyond the scope of this paper and would perhaps be more adequately debated in regards to industrial relations: e.g. the quasi absence of industrial $\underline{\text { conflict, industrial democracy under 'ultra-corporatism' and blurring lines between }}$ collectivism and individualism. However, we share the view that looking at the social foundations of governance can lead to a multi-layered and more nuanced examination of leadership. In essence, to recap the argument, harnessing manpower is vital to Singapore and Tripartism has long been pivotal to HRD strategies (Osman Gani and Tan, 1998, p. 418, 421). Human capital is existential to Singapore both as an economic and moral imperative. Leadership in Singapore can be usefully comprehended by looking at how governance has been set up to meet those two imperatives intertwining a system and a value system in a tight knit manner.

\subsection{Conclusion}

Tripartism in Singapore differs from European-style corporatisms, through which government agencies relayed by social partners orchestrate and diffuse their policy, often as a facilitative tool. Indeed, policy diffusion in Singapore happens rapidly because of closely knitted relationships, cooperation and collaborations between the tripartite actors arguably producing "faster, deeper, more effective transmission of state policy" as pointed out by Sheldon et al. (2015, p. 441).

With the recent focus on skills upgrade, the NTUC and SNEF are all geared-up to encourage workers to take advantage of the various government training grants. Employers, unions, education, and training providers are all guided by the direction set forth by the high-level Council for Skills, Innovation and Productivity, which is currently chaired by the Deputy Prime Minister, Mr. Tharman Shanmugaratnam. In keeping with Singapore's tripartite labour management system, the SkillsFuture Council was established as a tripartite body that, in the 
view of the MOM, is expected to "coordinate and drive a national effort to help Singaporeans develop skills relevant to the future, and build a future based on the mastery of skills in every job" (MOM, 2019).

Under the same initiative, SkillsFuture has identified certain sectors to focus on boosting national productivity. Further, an Industry Transformation Map across 23 sectors is being used under an Industrial Transformation Policy fostering new business models with the objective to retain talent and to deepen skills to increase value addition in an approach designed to meet each sector-specific need. As observed by Sakamoto and Sung (2018, p. 15): "the most useful insight from the Singapore approach is the need for a highly balanced approach that involves both the demand for higher and new skills as well as the supply to meet the new demand". However, although job quality and upskilling are important policy outcomes, productivity remains the primary concern in the mix: "raising productivity is not just our most important priority but enables us to build a better society. Higher productivity is the only sustainable way to raise incomes for ordinary Singaporeans, and provide jobs that give people a sense of responsibility and empowerment" (Shanmugaratnam, 2013, cited in Bali et al., 2019, p. 1).

Yet, evidence still suggests that labour foreign inbound has so far provided and continues to provide the primary input for economic growth. As one prominent observer was to comment in a discussion in late 2018: "employers are still on steroids with migrant labour." The Singapore government is aware that the volume of labour and associated migration has become a social dilemma. Hence, the productivity and skills formation agenda is getting even more central to governance. Interviewed in 2015, the MOM actually confirmed that the tightening of the labour market through restrictions of employment passes was to pressure the demand side to seek innovative ways to achieve productivity gains instead. 
The 2018 ILO report on Skills and the Future of Work: Strategies for Inclusive Growth in Asia and the Pacific stated that if "serious about achieving inclusive growth, there is more than just the demand and supply of skills to deal with. Policy must address the challenges of transition, such as identifying barriers and ensuring steady progress. These challenges mean that adjustments should be treated as societal and institutional and are not just coming from individuals" (Sakamoto and Sung, 2018, p. 16). It is thus a matter of governance. And indeed, how the SkillsFuture has been used to address upskilling is a demonstration of system-based leadership and coordination in policy-making.

Such an institutional approach in management development, we have observed, is embedded into the Singaporean model of governance and is intrinsic to the Confucian Junzi leadership that inspired Singaporean leaders and their commitment toward human capital development. Singapore is leading human capital development by example, and it will be interesting to assess how policies and social mechanism put in place and best practices, still a work-inprogress, can set a benchmark for the ASEAN, especially within Singapore's renewed Partnership Agreement with the ILO (ILO, 2018b) to promote Decent Work and contribute to the achievement of the Sustainable Development Goals in Asia. 


\section{References}

Alvesson, M. (2019), "Waiting for Godot: Eight major problems in the odd field of leadership studies", Leadership, Vol. 15((1)), pp. 27-43.

Amrine, D. (2013), The wit \& wisdom of Lee Kuan Yew [1923-2015], Didier Millet, Singapore Editions.

Ang, C.G. (2019), "Biography and history: The historiography of Lee Kuan Yew", Asian Studies Review, Vol. 43(3), pp. 544-561.

Armstrong, K.A. (2012), "EU social policy and the governance architecture of Europe 2020", Transfer: European Review of Labour and Research, Vol. 18 No. 3, pp. 285-300.

Bali, A., McKiernan, P., Vas, C. and Waring, O. (2019), Productivity and Innovation in SMEs : Creating Competitive Advantage in Singapore and South East Asia, Routledge Focus on Environment and Sustainability, Routledge, Abingdon, Oxon.

Barr, M.D. (2000), Lee Kuan Yew. The Beliefs Behind the Man, Curzon Press, Richmond, Surrey.

Bass, B. M. and Steidlmeier, P. (1999), "Ethics, character, and authentic transformational leadership behaviour", The Leadership Quarterly, Vol. 10 No. 2, pp. 181-217.

Bass, B.M. (1996), "Is there universality in the full range model of leadership?", International Journal of Public Administration, Vol. 19 No. 6, pp 731 - 761

Cheng, C. (2011), "Confucian global leadership in Chinese tradition: classical and contemporary", Journal of Management Development, Vol. 30 No. 7/8, pp. 647-662.

Coe, N.M. and Kelly, P.F. (2000), "Distance and discourse in the local labour market: The case of Singapore", Area, Vol. 32 No. 4, pp. 413-422.

Fu, P. and Tsui, A. (2003), "Utilizing printed media to understand desired leadership attributes in the People's Republic of China", Asia Pacific Journal of Management, Vol. 20 No. 4, pp. 423-446.

Gong, Y. and Jang, W. (1998), "Culture and development: reassessing cultural explanations on Asian economic development”, Development and Society, Vol. 27 No. 1, pp. $77-$ 97.

Haley, U.C.V., Low, L. and Toh, M.H. (1996), “Singapore Incorporated: reinterpreting Singapore's business environments through a corporate metaphor", Management Decision, Vol. 34 No. 9, pp. 17-28.

Hall, E. T. and Hall, M. R. (1989), Understanding cultural differences. Intercultural press.

Hong, M.T. and Lugg, A. (2015), The Rise of Singapore (2-Volume Set), World Scientific, Singapore. 
Hyman, R. (1999), “Imagined Solidarities: Can Trade Unions Resist Globalization?” in P. Leisink (Eed.), Globalization and Labour Relations, Cheltenham: Edward Elgar, Cheltenham, pp. 94-115.

International Labour Organisation (2018b), "ILO and Singapore moving forward to promote decent work in Southeast Asia", available at https://www.ilo.org/asia/mediacentre/news/WCMS_631487/lang--en/index.htm (accessed 19 Jan 2019).

International Labour Organization (2018a), “Asia-Pacific employment and social outlook 2018”, available at https://www.ilo.org/wcmsp5/groups/public/---asia/---robangkok/---sro-bangkok/documents/publication/wcms_649885.pdf (accessed $19 \mathrm{Jan}$ 2019).

Ip, P.K. (2011), "Practical wisdom of Confucian ethical leadership: a critical inquiry", Journal of Management Development, Vol. 30 No-(7/8, $)_{2}$ pp. 685-696.

Jullien, F. (1995), Le Détour et l'Accès. Stratégies du sens en Chine, en Grèce, Grasset. Translated as Detour and Access: Strategies of Meaning in China and Greece, MIT Press, 2004.

Jung, D.I. and Avolio, B.J. (2000), “Opening the black box: An experimental investigation of the mediating effects of trust and value congruence on transformational and transactional leadership",. Journal of Organizational Behavior, Vol 21(8), 949-964.

Kuah A.T.H., Le Queux, S. and Hassan, S. (2017), "L'ultra-corporatisme au service du Singaporean Core”, Chronique Internationale de l'IRES, Vol. 156, pp. 60-74.

Laulusa, L. (2008), "Confucianism and its implications for industrial relations in China", Journal of Management Spirituality and Religion, 2008, Vol. 5 No. 4, pp.385-403.

Le Queux, S., and Waring, P. (2010), "Australie/Singapour: deux exemples de résilience à la crise", -Chronique Internationale de l'IRES, No 127, pp 222-230.

Lee, K.Y. (2012), The Singapore Story: Memoirs of Lee Kuan Yew (Vol. 1), Marshall Cavendish, International Asia, Singapore.

Leggett, C. (2013), "Workforce development and skills formation in Singapore", in Benson, J., Gospel, H. and Zhu, Y. (Eds) Workforce Development and Skill Formation in Asia. Routledge Studies in the Growth Economies of Asia, Routledge, London, pp. 89-114.

Leggett, C. and Le Queux, S. (2014), “Unions as agency of migrant workers' discrimination and social exclusion", in New Frontiers for Citizenship at Work, CRIMT 2014 International Conference, 12-14 May.

Leggett, C., Kuah, A.T.H. and Gan, B. (2017), “Employers' associations in Singapore: Tripartite engagement', in Benson, J., Zhu, Y. and Gospel, H. (Eds), Employers' Associations in Asia: Strategy and Structure, Routledge, England, pp. 96-115. 
Leung, K. (2012), "Indigenous Chinese management research: like it or not, we need it", Management and Organization Review, Vol. 8 No. 1, pp. 1-5.

Lin, W. (2011), "Foreign workers should get training too", Straits Times, 9 September, Singapore Press Holdings, Singapore.

Locke, R.M. and Thelen, K. (1995), "Apples and oranges revisited: Contextualized comparisons and the study of comparative labor politics", Politics \& Society, Vol. 23(3), pp. 337-367.

Loh, O.H. (2018), Industrial Relations in Singapore: Practice and Perspective, Align Group, World Scientific, Singapore.

Makeham, J. (2008), Lost soul: "Confucianism” in contemporary Chinese academic discourse. Harvard University Press, Cambridge, MA.

McCann, L. (2014), International and Comparative Business. Foundations of Political Economies, Sage, London.

McElhatton, E. and Jackson, B. (2012)), "Paradox in harmony: Formulating a Chinese model of leadership.". Leadership, Vol 8(4), 441-461.

Miao, Q., Newman, A. and Lamb, P. (2012), “'Transformational leadership and the work outcomes of Chinese migrant workers: The mediating effects of identification with leader.",. Leadership, Vol 8(4), 377-395.

Ministry of Manpower (2001), Human Capital: Ministry of Manpower Annual Report 2001, Ministry of Manpower, Singapore.

Ministry of Manpower (2018), "Singapore yearbook of manpower statistics 2018”, available at https://stats.mom.gov.sg/Pages/Singapore-Yearbook-Of-Manpower-Statistics2018-Key-Economic-Indicator.aspx (accessed 19 Jan 2019).

Ministry of Manpower (2019), "SkillsFuture", available at https://www.mom.gov.sg/employment-practices/skills-training-anddevelopment/skillsfuture (accessed 19 Jan 2019).

Mouton, N. (2019), “A literary perspective on the limits of leadership: Tolstoy's critique of the great man theory", Leadership, Vol. 15(1), pp. 81-102.

Ng, H-Y. (2018), "Decentralised Institutions and Electoral Authoritarianism: The Case of Town Councils in Singapore", Asian Studies Review, Vol. 42 No. 3, pp. 469-478.

Ohno, I. and Kitaw, D. (2011), "Productivity movement in Singapore", Kaizen National Movement: A Study of Quality and Productivity Improvement in Asia and Africa, JICA-GRIPS, Tokyo, pp. 49-68.

Osman-Gani, A.M. and Tan, W.L. (1998), "Human resource development: the key to sustainable growth and competitiveness of Singapore", Human Resource Development International, Vol. 1(4), pp. 417-432 
Pezzutto, S. (2019), "Confucianism and capitalist development: From Max Weber and Orientalism to Lee Kuan Yew and New Confucianism", Asian Studies Review, Vol 43(:2), pp. 224-238.

Plate, T. (2013), Giants of Asia: Conversations with Lee Kuan Yew: Citizen Singapore: How to build a nation, Marshall Cavendish International Asia, Singapore.

Pun, K. F., Chin, K. S., and Lau, H. (2000), “A review of the Chinese cultural influences on Chinese enterprise management", International Journal of Management Reviews, Vol. 2 No. 4, pp. 325-338.

Rarick, C.A. (2009), The historical roots of Chinese cultural values and managerial practices. Journal of International Business Research, Vol 8, pp. 59-66.

Scott, J. (1990), A Matter of Record: Documentary sources in social research, Polity Press, Cambridge.

Seow, J. (2016), “Two new statutory boards set up to oversee skills and employment”, Straits Times, 12 January, Singapore Press Holdings, Singapore.

Shanmugaratnam, T. (2009), "Keeping Jobs, Building For The Future”, Speech delivered the Budget Statement for the Financial Year 2009, available at:

https://www.mof.gov.sg/Newsroom/Press-Releases/Keeping-Jobs-Building-for-theFuture(accessed 22 Jan 2019).

Sheldon, P., Gan, B. and Morgan, D. (2015), "Making Singapore's tripartism work (faster): the formation of the Singapore National Employers' Federation in 1980", Business History, Vol. 57 No. 3, pp. 438-460.

Silverman, D. (2000), “Analysing talk and text”, in Denzin, N.K. and Lincoln, Y.S. (Eds), Handbook of Qualitative Research, 2nd Ed, SAGE, California, pp. 821-835.

Taormina, R.J. and Selvarajah, C. (2005). Perceptions of leadership excellence in ASEAN nations. Leadership, Vol 1 (3), 299-322.

$\underline{\text { Teo, T. (2019), "Perceptions of meritocracy in Singapore: Inconsistencies, contestations and }}$ biases", Asian Studies Review, Vol. 43(:2), pp. 184-205.

Trevino, L.K. and Brown, M.E. (2007), "Ethical leadership: a developing construct”, in Nelson, D.L. and Cooper, C.L. (Eds), Positive Organizational Behavior, Sage, London, pp. 101-16.

Trevino, L.K., Hartman, L.P. and Brown, M. (2000), "Moral person and moral manager: how executives develop a reputation for ethical leadership", California Management Review, Vol. 42, pp. 128-42.

Tu, W. (1984), Confucian Ethics Today. The Singapore Challenge, Federal Publications, Singapore.

Walumbwa, F.O., Lawler, J.J., Avolio, B.J., Wang, P. and Shi, K. (2005), Transformational leadership and work-related attitudes: The moderating effects of collective and self- 
efficacy across cultures. Journal of Leadership and Organizational Studies, Vol 11 No. (3), p. 2-16.

Waring, P. and Lewer, J. (2013), The global financial crisis, employment relations and the labour market in Singapore and Australia, Asia Pacific Business Review, Vol. 19 No. 2, ppp. 217-229.

Weber, M. (1968). The religion of China: Confucianism and Taoism, The Free Press, New York

New York: The Free Press. Wiarda, H.J. (1996), Corporatism and Comparative Politics: The Other Great "Ism", Comparative Politics Series, Routledge, Oxford.

Wong, C.T.N. (2013), Confucian Junzi Leadership: A model of authentic moral transformation for educational leaders, (Doctoral dissertation, Education: Faculty of Education, Simon Fraser University), available at http://summit.sfu.ca/item/12789 (accessed 28 Feb 2019).

World Bank, World Development Indicators (2019), “GDP growth [Data file]”, available at https://data.worldbank.org/indicator/NY.GDP.MKTP.KD.ZG? contextual=default\&1 ocations $=\mathrm{SG}($ accessed 19 Jan 2019).

Zhao, S.M. and Jiang, C.Y. (2009), "Learning by doing: emerging paths of Chinese management research", Management and Organization Review, Vol. 5 No. 1, pp. 107-119 
Figure 1: Singapore's GDP, GDP growth rate, labour productivity, and real wages

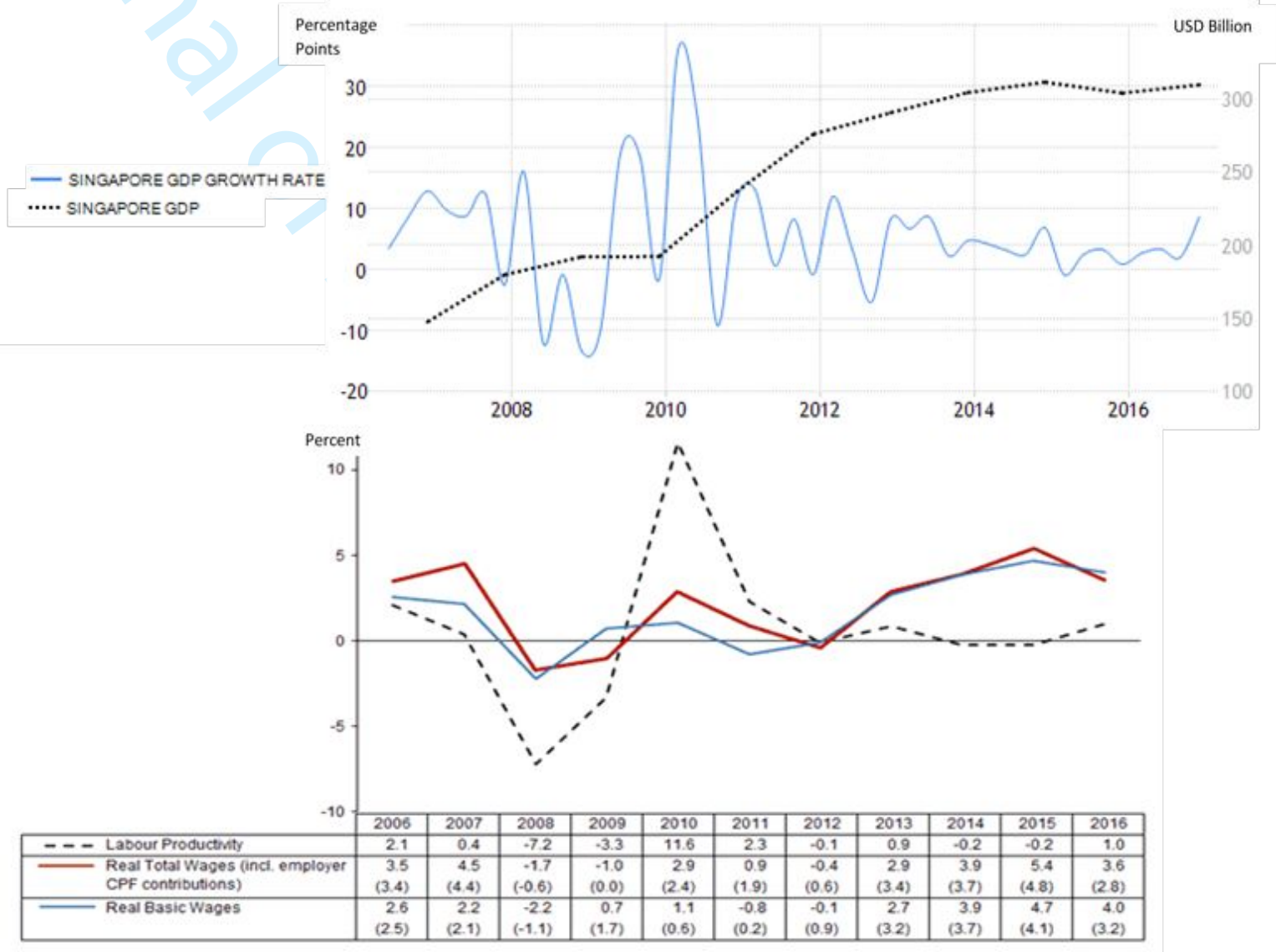

Sources: Survey on Annual Wage Changes, Manpower Research and Statistics Department, Ministry of Manpower; Ministry of Trade and Industry (for Productivity data); and The World Bank (for GDP data) 
Figure 2: Change in Median Gross Monthly Income from Work of Singapore's Residents

\begin{tabular}{|c|c|c|c|c|c|c|}
\hline \multirow[b]{2}{*}{ Mid-Year } & \multicolumn{3}{|c|}{ Annualized Change (\% p.a.) } & \multicolumn{3}{|c|}{ Cumulative Change (\%) } \\
\hline & $\begin{array}{l}2008- \\
2018\end{array}$ & $\begin{array}{l}2008- \\
2013\end{array}$ & $\begin{array}{l}2013- \\
2018\end{array}$ & $\begin{array}{l}2008- \\
2018\end{array}$ & $\begin{array}{l}2008- \\
2013\end{array}$ & $\begin{array}{l}2013- \\
2018\end{array}$ \\
\hline Nominal & $4.4 \%$ & $5.0 \%$ & $3.7 \%$ & $53.2 \%$ & $27.9 \%$ & $19.8 \%$ \\
\hline $\operatorname{Real}^{\wedge}$ & $2.7 \%$ & $1.9 \%$ & $3.5 \%$ & $30.0 \%$ & $9.7 \%$ & $18.7 \%$ \\
\hline
\end{tabular}

Source: Gross Monthly Income From Work - Comprehensive Labour Force Survey, Manpower Research \& Statistics Department, MOM; Latest figures published in: Labour Force in Singapore

\section{Figure 3: Three Stages of Singapore's Productivity Movement}

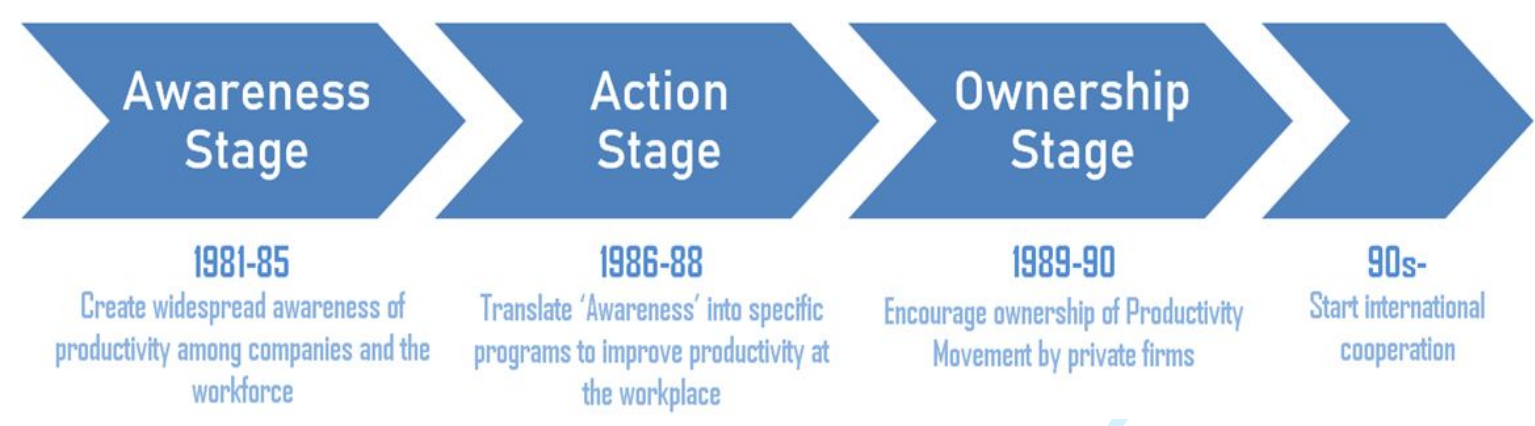

Source: Ohno and Kitaw (2011) 
Figure 4: Average Annual Growth in Wages and Productivity (2010-2016)

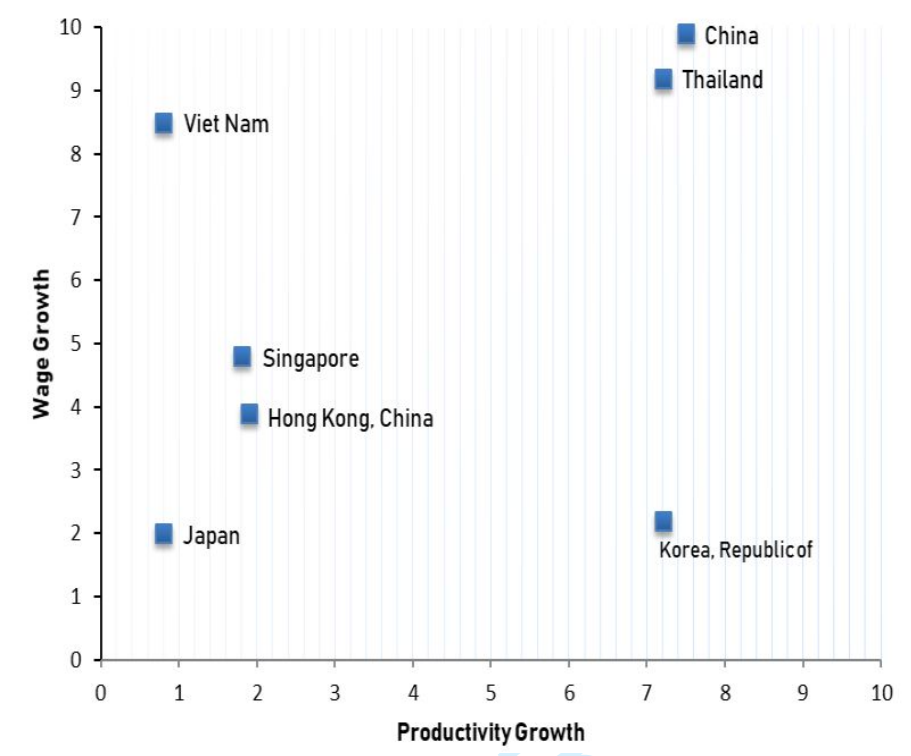

Source: Adapted from ILO, 2018a, p. 4 


\section{Figure 1: Singapore's GDP, GDP growth rate, labour productivity, and real wages}

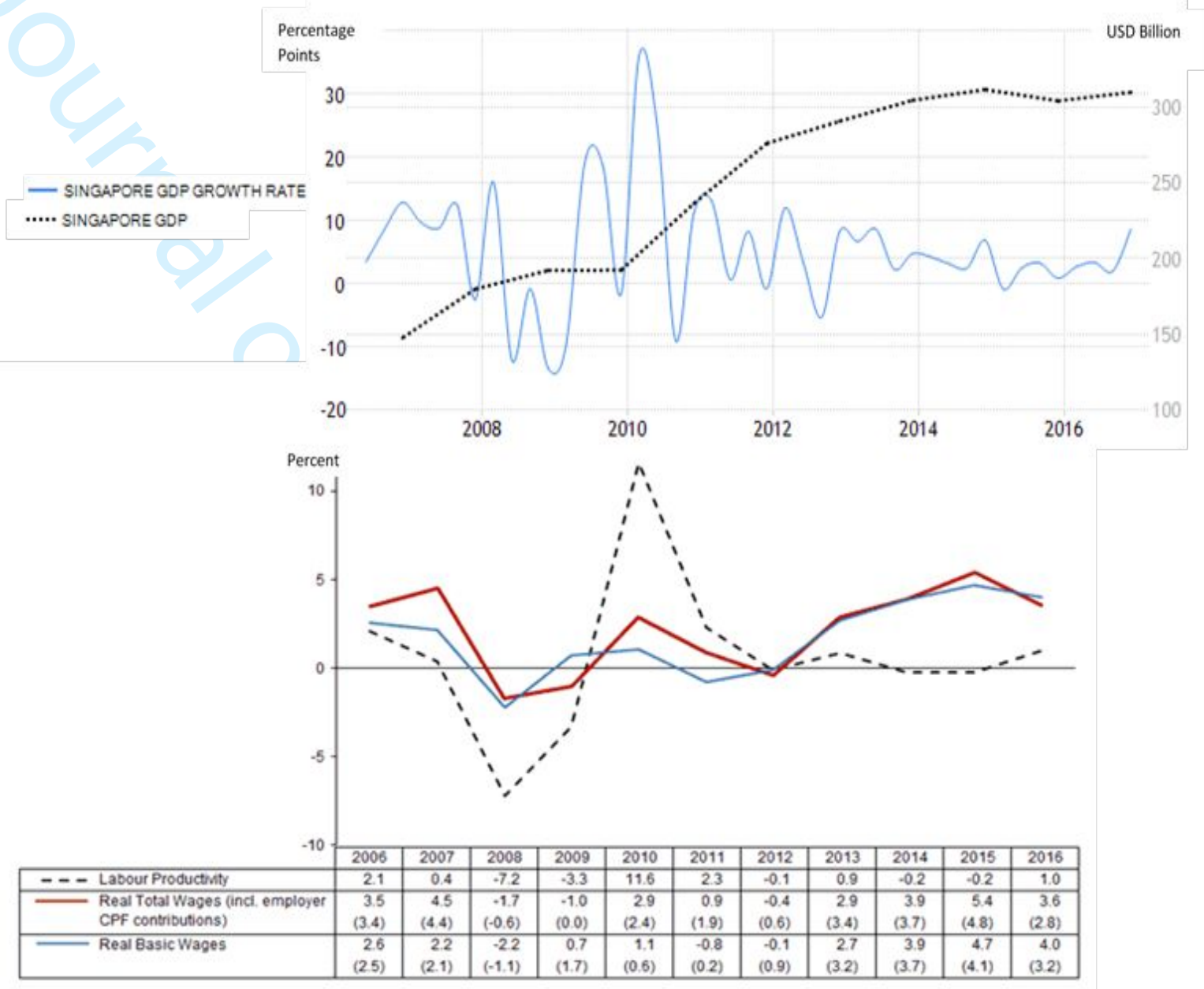

Sources: Survey on Annual Wage Changes, Manpower Research and Statistics Department, Ministry of Manpower; Ministry of Trade and Industry (for Productivity data); and The World Bank (for GDP data) 
Figure 2: Change in Median Gross Monthly Income from Work of Singapore's Residents

\begin{tabular}{|c|c|c|c|c|c|c|}
\hline \multirow[b]{2}{*}{ Mid-Year } & \multicolumn{3}{|c|}{ Annualized Change (\% p.a.) } & \multicolumn{3}{|c|}{ Cumulative Change (\%) } \\
\hline & $\begin{array}{l}2008- \\
2018\end{array}$ & $\begin{array}{l}2008- \\
2013\end{array}$ & $\begin{array}{l}2013- \\
2018\end{array}$ & $\begin{array}{l}2008- \\
2018\end{array}$ & $\begin{array}{l}2008- \\
2013\end{array}$ & $\begin{array}{l}2013- \\
2018\end{array}$ \\
\hline Nominal & $4.4 \%$ & $5.0 \%$ & $3.7 \%$ & $53.2 \%$ & $27.9 \%$ & $19.8 \%$ \\
\hline Real $^{\wedge}$ & $2.7 \%$ & $1.9 \%$ & $3.5 \%$ & $30.0 \%$ & $9.7 \%$ & $18.7 \%$ \\
\hline
\end{tabular}

Source: Gross Monthly Income From Work - Comprehensive Labour Force Survey, Manpower Research \& Statistics Department, MOM; Latest figures published in: Labour Force in Singapore 
Figure 3: Three Stages of Singapore's Productivity Movement

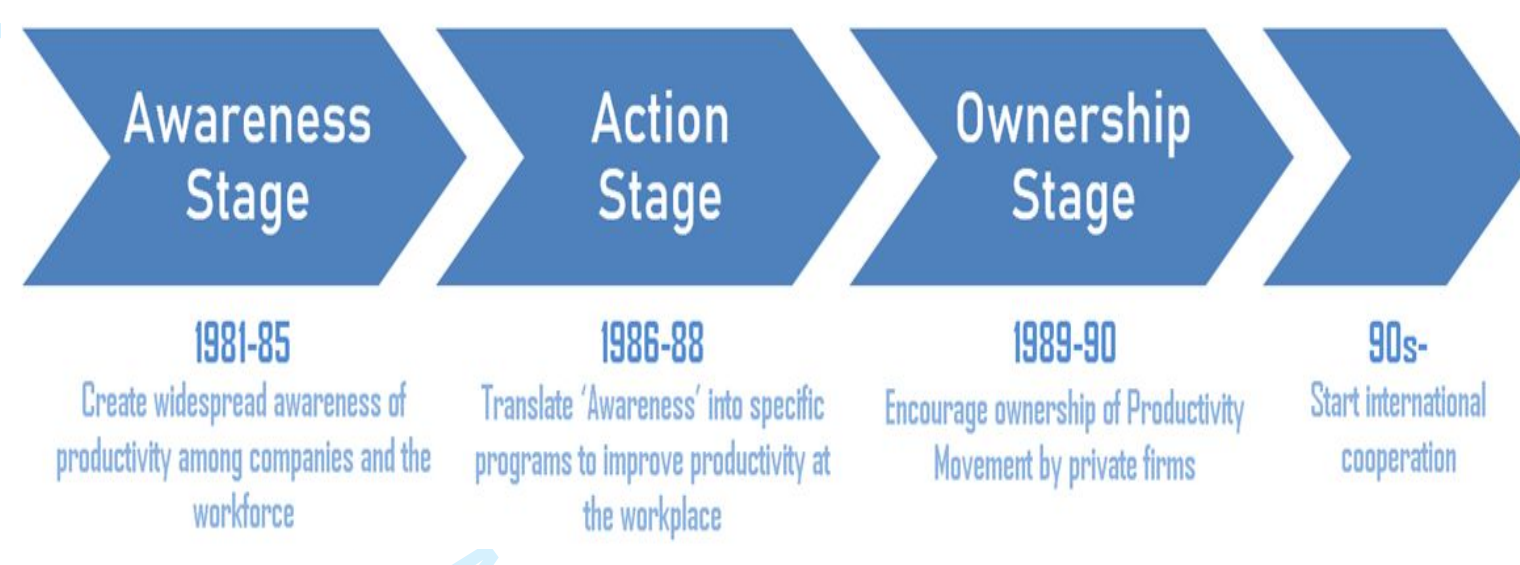

Source: Adapted from Ohno and Kitaw (2011) 
Figure 4: Average Annual Growth in Wages and Productivity (2010-2016)

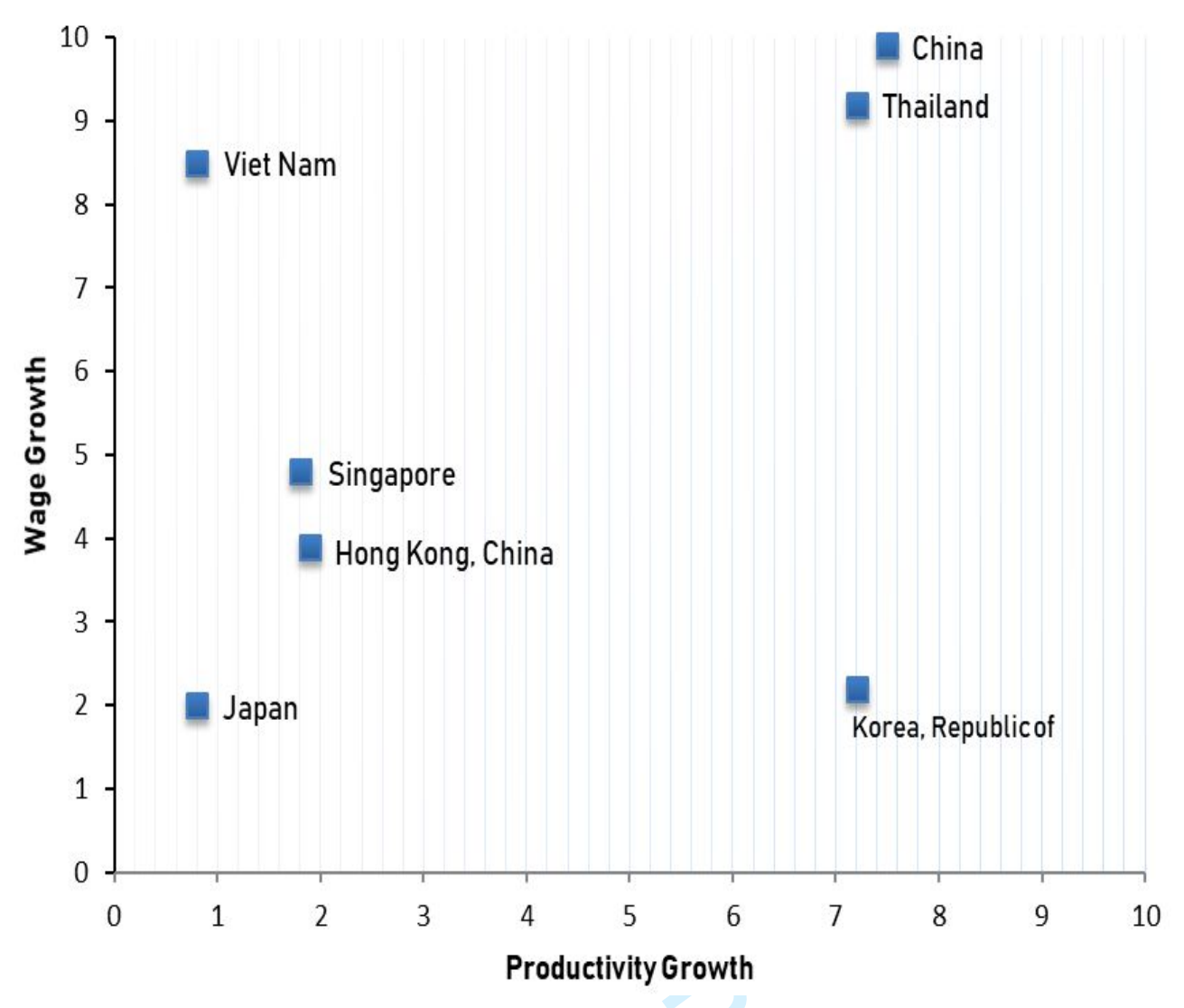

Source: Adapted from ILO, 2018a, p. 4 